\title{
EVALUATION OF RESOURCES AND POTENTIAL MEASUREMENT OF WIND ENERGY TO DETERMINE THE SPATIAL PRIORITIES FOR THE CONSTRUCTION OF WIND- DRIVEN POWER PLANTS IN DAMGHAN CITY
}

(D) Rahim Zahedi
iD Abolfazl Ahmadi
Reza Eskandarpanah
Mohammadhossein $^{3}$
Akbari $^{4}$

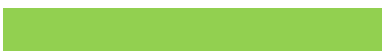

\section{Article History}

Received: 27 December 2021 Revised: 31 January 2022 Accepted: 15 February 2022 Published: 22 February 2022

\section{Keywords}

Geographical information system Location criteria

Fuzzy logic

Windfarm

Damghan city

GIS

Wind energy.

\author{
${ }^{1,2}$ School of Advanced Technologies, Iran University of Science and Technology, \\ Tehran, Iran. \\ 'Email: rahimzahedi@ut.ac.irTel:+989126801778 \\ EEmail:a_ahmadi@iust.ac.ir Tel: +989124394740 \\ ${ }^{3,4}$ Department of Energy Systems Engineering, Islamic Azad University \\ Science and Research Branch, Tehran, Iran. \\ ${ }^{3}$ Email: reza.eskandarpanah@srbiau.ac.ir Tel:+989126603266 \\ "Email:mh.akbariasl@srbiau.ac.ir Tel: +989186292968
}

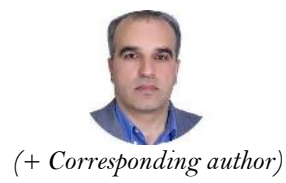

(+ Corresponding author)

\section{ABSTRACT}

The rate of energy consumption is increasing worldwide due mainly to economic advancement and population growth. As a result, renewable energy sources have gained unprecedented popularity. Wind power has attracted much attention recently as it is economical and does not create environmental pollution. One vital factor that must be considered in the construction of a wind-driven power plant is the selection of a suitable location. Location choice is highly dependent upon the outcome of investigating a potential construction site. This research, along with investigating the effectiveness of parameters for determining a potential location, aims to explore the elements that play a major role in identifying and selecting an optimal wind farm site. The most suitable locations for the construction of wind farms in the city of Damghan were identified and selected through analyzing and integrating maps using GIS software. Within the whole Damghan city area, about $2,240 \mathrm{~km}^{2}$, which comprises $16 \%$ of the city's area has been identified as suitable for establishing wind-driven power plants. By considering the relevant elements and keeping an appropriate distance between the plants to avoid power reduction, it is estimated that a total energy output of about 1,000 MW can be produced by wind-driven power plants in this city.

Contribution/Originality: This research is to identify and prioritize suitable locations for the construction of wind-driven power plants in Damghan city, Semnan province that will be met through employing fuzzy integration logic in a GIS environment together with Multi-Criteria Decision-Making (MCDM) methods.

\section{INTRODUCTION}

Existing, relevant studies indicate that energy consumption has a great influence on national development and income levels worldwide. Such significant impacts have increased global power demand (Ellabban, Abu-Rub, \& Blaabjerg, 2014). During recent decades, population growth, booming industries, and economic expansion and development have increased the consumption of fossil fuels. This has resulted in the environment and natural resources of many nations being at risk of destruction, and has brought about adverse environmental impacts such as greenhouse gas emission and climate change (Dabbaghiyan, Fazelpour, Abnavi, \& Rosen, 2016; Shu, Li, \& Chan, 2015). 
Since 2011 , yearly energy demands have grown by about $1.8 \%$. According to estimates made by the International Energy Agency (IEA), 65\% of so-called growth has taken place in developing countries. Estimates show that the rate of energy consumption could reach 31,675 TWh by 2030, while until 2004, the global energy production rate was 17,450 TWh (Dincer, 2011). There are finite fossil fuel reserves on earth, and the increase in consumption of such resources has resulted in their considerable depletion (Zahedi, Ahmadi, \& Dashti, 2021). The rise in electricity demands has compelled several countries to increase their dependance on the consumption of renewable energy sources using wind, solar, biomass, geothermal, or wave technologies. Most countries believe that renewable energy sources are more stable than fossil fuels and that they are more environmentally friendly and much more abundant. They also produce zero emissions. The transformation to consuming renewable sources of energy is essential for the protection of our environment (Quan \& Leephakpreeda, 2015).

In 2016, renewable energy's generating capacity experienced its largest annual growth of $160 \mathrm{GW}$. In other words, the total capacity of renewable energy sources grew by $9 \%$, more than $2.017 \mathrm{GW}$, when compared with 2015 . These energy sources comprised $24.5 \%$ of electrical energy generated worldwide by the end of 2016 . In the same year, wind energy was in third place among sources of renewable energy producing about 13,500 MW of the world's electrical energy.

The use of wind energy is globally viewed as essential. Accordingly, the World Wind Energy Association (WWEA), an internationally established organization, has a single mission - to ensure the development and expansion of wind-driven power plants throughout the world to engender optimal economic and environmental conditions. According to the WWEA, in 2014, China could satisfy $45 \%$ of its annual power requirements by installing wind turbines producing $23 \mathrm{GW}$ in a year. China is the leading country in the wind energy market with an installed capacity of $114 \mathrm{GW}$. The US and Germany take second and third place, respectively, in the consumption of wind energy with a total installed capacity of $65 \mathrm{GW}$ and $39 \mathrm{GW}$, respectively. In 2019 , the total capacity of these three countries was estimated to be $666 \mathrm{GW}$ (Elibol, 2015).

Wind energy is superior to that produced by fossil fuels as the sources and reserves of this type of energy are abundant. It has zero fuel and operating costs and is completely green, with no pollutant output. Thus, the technology around wind turbines has improved rapidly in recent decades and several countries have put significant efforts into improving the rate of energy generation through this highly available and safe resource (Murthy \& Rahi, 2016).

Research on wind as an accessible and potential energy source began in 1960. In 1970, by the start of oil crisis which resulted in fuel prices increasing, the costs concerning renewable energy source technologies started to mitigate. This trend resulted in a significant rise in the research aimed at renewable sources of energy until 2000 (Fazelpour, Soltani, Soltani, \& Rosen, 2015). Consuming less crude oil and producing lower levels of carbon dioxide are among the motives to make use of wind energy in different countries (Zahedi \& Rad, 2022). The global rate of wind power generation has reached $20 \%$ a year during the past decade. Wind energy has become an essential source of power globally and since 2018 , the global capacity has reached $600 \mathrm{GW}$. To exploit wind energy effectively, there is a dire need for precise information concerning wind characteristics in the area of the project (Zahedi, Ahmadi, \& Sadeh, 2021). The Global Wind Energy Council (GWEC) has estimated the value of the wind energy industry up to 2040 will reach 67 billion dollars, with approximately 10MW of this being available to be used (Fazelpour et al., 2015).

Various elements must be considered for the construction of wind turbines. The most vital are potential measurement, wind analysis, the estimation of annual wind power generation, and the economic analysis of potential locations. Such analyses and measurements can inform the feasibility and profitability of an investment in wind turbines in any given location (Yang, Tavner, Crabtree, Feng, \& Qiu, 2014). Various distributions such as Rayleigh, Weibull, Pearson, and Johnson can be used to measure the wind power potential of a potential site. The Weibull distribution is used by many researchers for a variety of purposes due to its high precision (Akdağ \& Güler, 2018). 
Besides identifying an optimal location for a potential wind farm, and considering the uncertainty and instability of wind speed, building an accurate wind energy prediction model is of paramount importance. Therefore, in addition to spatial analysis, there is increasing need for wind-regime modeling to predict the wind's behavior in the future. To this end there is a plethora of studies focused on wind energy estimation through data analysis using the Probability Density Function (PDF).

These studies have used the latest global-spatial data from the National Renewable Energy Laboratory (NREL) to classify wind energy density into seven classes, namely, Poor (O-200 W/m²), Marginal (200-300 W/m²), Fairly Good $\left(300-400 \mathrm{~W} / \mathrm{m}^{2}\right)$, Good $\left(400-500 \mathrm{~W} / \mathrm{m}^{2}\right)$, Great $\left(500-600 \mathrm{~W} / \mathrm{m}^{2}\right)$, Outstanding $\left(600-800 \mathrm{~W} / \mathrm{m}^{2}\right)$, and Wonderful (>800 W/m²) (Bina, Jalilinasrabady, Fujii, \& Farabi-Asl, 2018).

The European Wind Energy Association (EWEA) defined wind speed classifications as Fairly Good (v_6.5 m/s), Good (v_7.5 m/s), and Very good (v_ 8.5 m/s) (Fazelpour, Markarian, \& Soltani, 2017).

The aim of this research is to identify and prioritize potential locations for constructing wind-driven power plants in Damghan city, Semnan province that will be met through the employment of fuzzy integration logic in a GIS environment along with Multi-Criteria Decision-Making (MCDM) methods.

\section{WIND ENERGY IN THE WORLD}

According to the GWEC, the capacity of wind power plants in the world reached 318,105 MW in 2013 and showed considerable growth rate in the ensuing five years.

Figures 1 and 2 show that 200,000 MW of the total generated capacity was obtained in the next five years. Also notable is the fact that regardless of a heavy global economic recession, there was a $12.5 \%$ growth in the wind energy field in 2018 (Rao, 2019).

By utilizing wind energy, we can produce $18 \%$ of the world's electrical energy by 2050. Currently, only $2.6 \%$ of the world's electricity is produced by wind energy. To achieve this goal, the industry's 300 GW capacity should increase by eight to ten times.

The annual cost of the wind energy industry is currently estimated to be 78 billion dollars. This is predicted to reach 150 billion dollars by 2050 (Rusu, 2020). Such a rate of growth in wind energy will avoid yearly $\mathrm{CO} 2 \mathrm{emissions}$ of about $4.8 \mathrm{Gt}$ up to 2050 . Also, using wind energy until 2050 would result in a $25 \%$ decrease in the cost of wind energy generation on land and a 45\% drop in wind energy production expenses in water (Beiter et al., 2016).

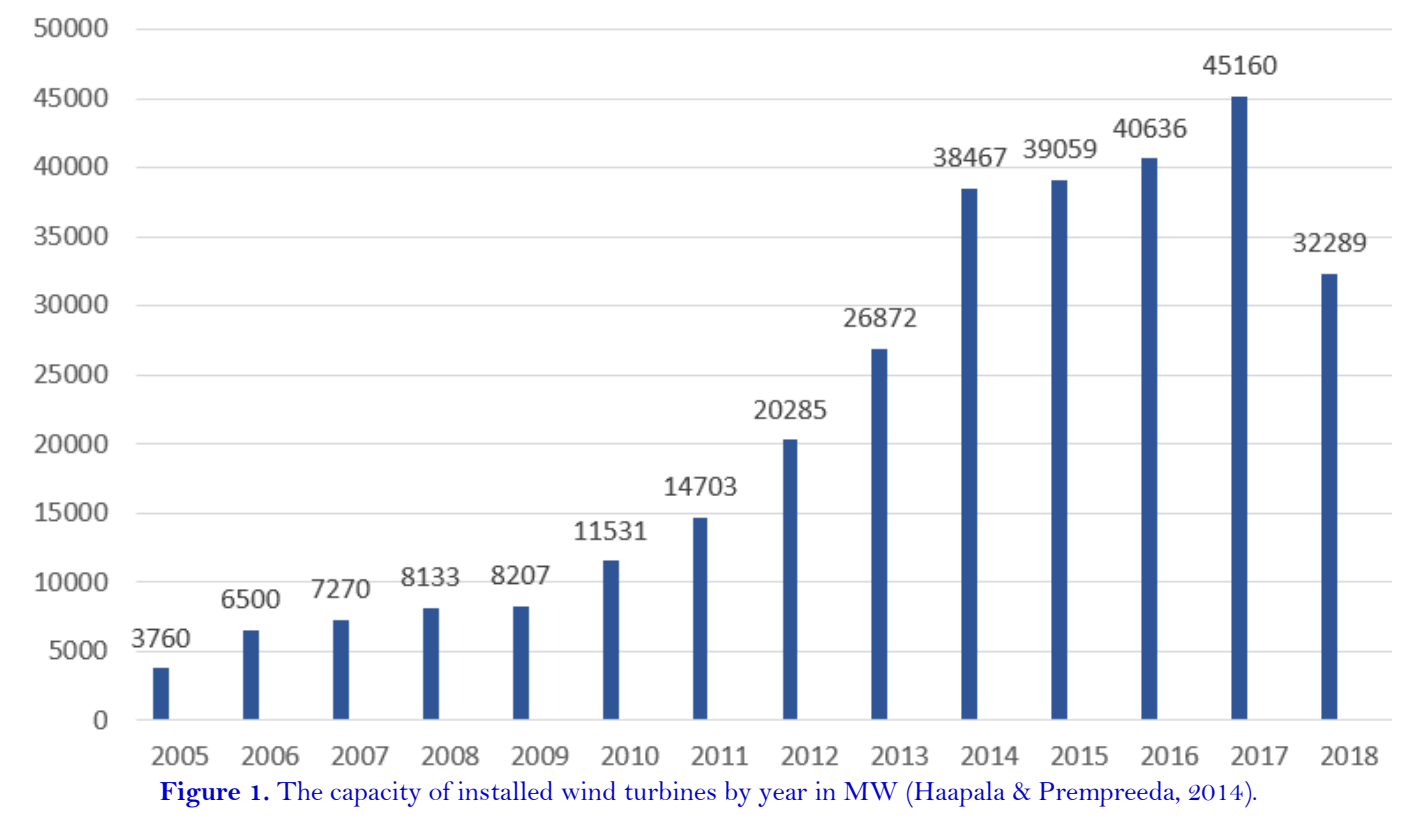




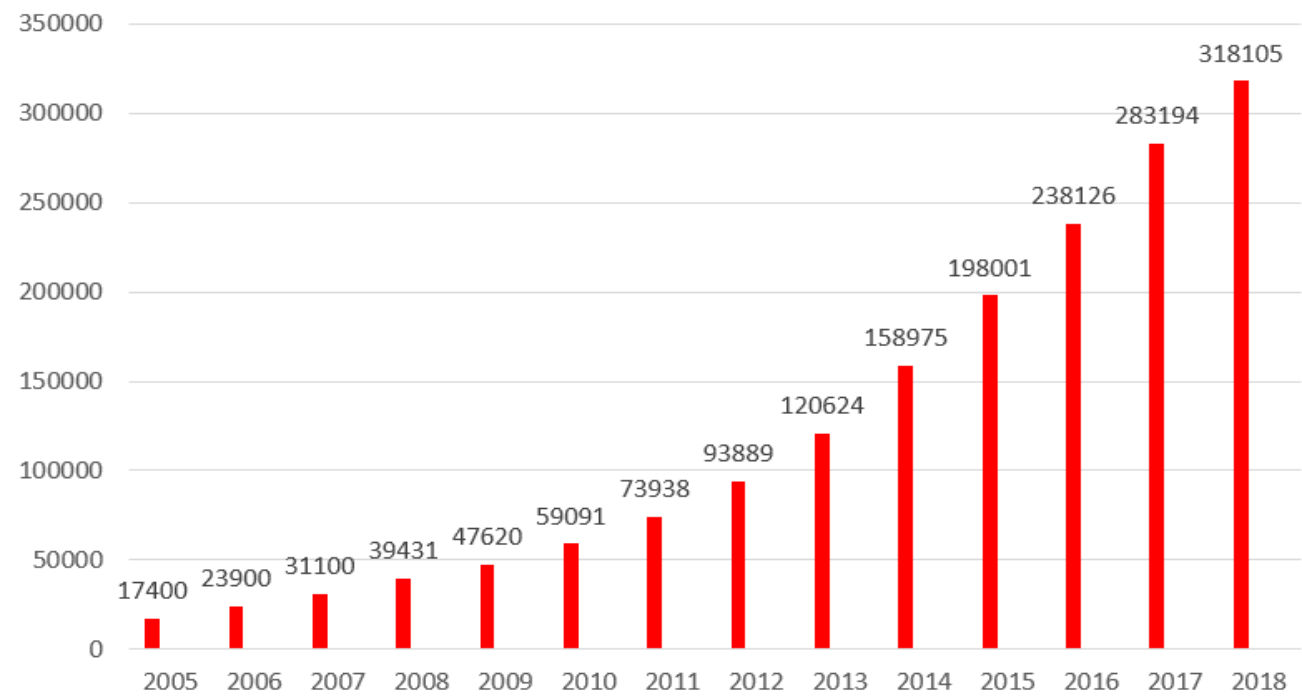

Figure 2. Total installed capacity of wind turbines by the end of 2018 in terms of MW.

\section{WIND ENERGY IN IRAN}

Various wind energy parameters including speed, direction, and temporal and spatial diversity might lower the reliability rate and disrupt the optimal functionality of a wind power system. In recent years, researchers have carried out numerous studies on wind potential and its characteristics in different parts of the world, several of which have been in Iran concerning the evaluation of areas with acceptable potential for utilizing wind energy. A good number of wind turbines have already been installed in several provinces with suitable wind energy potential (Dabbaghiyan et al., 2016).

In Iran, the capacity of electricity generation through wind energy is estimated to be around 15,000 MW (Tavana et al., 2019). It is predicted that between 2018 and 2027, a capacity of $12 \mathrm{GW}$ will be added to the Middle East's wind energy capacity. Saudi Arabia, Iran, and Jordan will be the leading countries in wind capacity growth and $70 \%$ of their growth rate will be installed. Iran's first wind farm was established 25 years ago in the city of Manjil. Today, there are 18 wind farms in Iran with a nominal capacity of 283 MW. The national production rate is $2.5 \mathrm{MW}$ wind turbines which is a significant share among renewable wind energy sources Sohrab, Rafiee, Karkoodi, and Parvin (2019). As mentioned (Sohrab et al., 2019), according to research, the city of Manjil in Iran is one of the most suitable locations for the installation of wind turbines. Investigations into the average wind speed in the city of Babak in Kerman province indicate that this city is also suitable for the establishment of wind farms. Other studies on wind potential carried out in Semnan province demonstrate the suitableness of implementing wind energy in the five cities of Biarjmand, Garmsar, Damghan, Shahroud, and Semnan. In Semnan province, the cities of Damghan and Semnan have the best wind sources. Wind speed has been investigated at altitudes of 10, 30, and 40 meters in the Binaloud area in Khorasan Razavi province. The investigation shows that the 40-meter altitude of this area offers considerable energy potential and carrying out wind energy-related projects there is economically justified. Also, an investigation was carried out in the Harat area in the center of Khatam town in the southernmost part of Yazd province. The results indicate this area has acceptable annual wind speeds of $5.05 \mathrm{~m} / \mathrm{s}$ and $6.86 \mathrm{~m} / \mathrm{s}$ at 10 and 40 meters high, respectively (Fazelpour et al., 2017).

Iran's current capacity to produce electricity through renewable sources is $660 \mathrm{MW}$, with an additional 420 MW under construction. Wind farms can produce $40 \%$ of the electricity produced by all renewable sources. A fundamental advantage of utilizing renewable energy sources is creating job opportunities (Sohrab et al., 2019). According to investigations in Damghan city over five years, the average wind speeds at the three altitudes of 10, 30, and 40 meters are, respectively, $3.90 \mathrm{~m} / \mathrm{s}, 5.14 \mathrm{~m} / \mathrm{s}$, and $5.52 \mathrm{~m} / \mathrm{s}$ (Fazelpour et al., 2015). A specification of the wind turbine sites in operation in Iran is shown in Table 1. 
Table 1. Specifications of wind turbine sites in operation in Iran in 2017 (Erfani, Ghasempour, \& Oraee, 2017).

\begin{tabular}{|c|c|c|c|c|c|}
\hline \multirow{2}{*}{$\begin{array}{l}\text { Wind } \\
\text { power plant }\end{array}$} & \multirow[t]{2}{*}{ Site } & \multirow[t]{2}{*}{ State } & \multirow[t]{2}{*}{ City } & \multicolumn{2}{|c|}{ Installed turbines } \\
\hline & & & & Number & Capacity (kW) \\
\hline \multirow[t]{5}{*}{ Manjil } & Paskulan & Gilan & Rudbar & 22 & 14,520 \\
\hline & Rudbar & Gilan & Rudbar & 4 & 2,150 \\
\hline & Siahpoush & Gilan & Rudbar & 44 & 29,040 \\
\hline & Manjil & Gilan & Rudbar & 31 & 13,250 \\
\hline & Harzevil & Gilan & Rudbar & 27 & 13,500 \\
\hline Binaloud & & Khorasan & Neyshabur & 43 & 28,380 \\
\hline \multirow[t]{2}{*}{ Sahand } & $\begin{array}{c}\text { Sahand University of } \\
\text { Tabriz } \\
\end{array}$ & East Azarbaijan & Tabriz & 1 & 10 \\
\hline & Tabriz & East Azarbaijan & Tabriz & 3 & 1,980 \\
\hline Lootak & Zabol & $\begin{array}{c}\text { Sistan and } \\
\text { Baluchestan } \\
\end{array}$ & Zabol & 1 & 660 \\
\hline $\begin{array}{l}\text { Babakuhi } \\
\text { Shiraz }\end{array}$ & Babakuhi & Fars & Shiraz & 1 & 660 \\
\hline $\begin{array}{l}\text { Mahshahr } \\
\text { Khuzestan }\end{array}$ & Mahshahr & Khuzestan & Mahshahr & 1 & 660 \\
\hline $\begin{array}{l}\text { Sarein } \\
\text { Ardabil }\end{array}$ & $\begin{array}{l}\text { Sarein } \\
\text { Ardabil }\end{array}$ & Ardabil & Ardabil & 1 & 660 \\
\hline $\begin{array}{l}\text { Soffeh } \\
\text { Isfahan }\end{array}$ & $\begin{array}{l}\text { Soffeh } \\
\text { Isfahan }\end{array}$ & Isfahan & Isfahan & 1 & 660 \\
\hline \multicolumn{2}{|l|}{ Total } & - & - & 180 & 106,130 \\
\hline
\end{tabular}

\section{CASE STUDY DESCRIPTION}

According to current country divisions, Semnan province has five main cities comprising Damghan, Semnan, Shahroud, Garmsar, and Mehdishahr which are further divided into 13 districts, 17 towns, and 29 rural areas. The total area of Semnan province is $97,491 \mathrm{~km}^{2}$. It is located at longitude between 51 degrees 51 minutes and 57 degrees 3 minutes east of the Greenwich Meridian, and latitude between 34 degrees 13 minutes and 37 degrees 20 minutes north of the equator (Mohammadi, Mostafaeipour, \& Sabzpooshani, 2014). North of Semnan province are North Khorasan, Golestan, and Mazandaran provinces. Tehran and Qom provinces are on the west, south are Yazd and Isfahan, and its eastern neighbor is Khorasan Razavi. Semnan city is the capital of Semnan province. The province is located on the southern slopes of the Alborz mountain range, with its height decreasing from north to south, and it leads to Dasht-e-Kavir.

Moradi, Yousefi, Noorollahi, and Rosso (2020) carried out a study using the MCDM approach to identify suitable wind farm locations in Alborz province, creating a classification map to depict the final selected sites. The results of the study indicate that the southeast part of Alborz province, including Karaj city and Nazar Abad town, has the highest priority. Therefore, it can be concluded that $80 \%$ of the province lacks suitability for building wind farms (Moradi et al., 2020).

El Khchine, Sriti, and Elyamani (2019) made use of statistical methods, namely the Weibull probability density function, to evaluate wind energy potential as an energy source in the Morocco area, especially the cities of Taza and Dakhla. To measure the Weibull parameters using the average wind speed at one-hour intervals, different methods including wind diversity, power density, standard deviation, and WAsP were used. The wind data were collected at 50 meters altitude over a three-year period from 2016 to 2018 . Weibull's monthly parameter values, on average, were $5.01 \mathrm{~m} / \mathrm{s}$ in Taza and $9.04 \mathrm{~m} / \mathrm{s}$ in Dakhla. The results of the study indicated that the highest wind potential values in Dakhla occur in the months of March, July, September, and December. The same values are the highest in Taza from December to March. Additionally, the Dakhla site manifests a high wind potential with a yearly wind power density of $435.96 \mathrm{~W} / \mathrm{m}^{2}$. However, Taza site's potential is weaker, with an annual density of $122.91 \mathrm{~W} / \mathrm{m}^{2}(\mathrm{El}$ Khchine et al., 2019). 
Akdağ and Güler (2018) proposed a new method for estimating Weibull parameters called the Alternative Moment Method (AMM). This method is analytical which means it has no need for a repetitive cycle. The efficiency and accuracy of the method are evaluated by its comparison with the common methods of parameter assessment. The results of graphic comparison showed that the AMM is more efficient than both the Justus Moment Method (JMM) and the Novel Energy Pattern Factor Method (NEPFM). While the error average of the AMM was $3.53 \times 10^{-7}$, that of JMM and NEPFM were $0.63 \%$ and $0.0031 \%$, respectively. The AMM is considered valid with a comparison regarding its precision in estimating wind turbine energy in 144 cases. AMM's average error in estimating the output energy of $750 \mathrm{KW}$ and $1,600 \mathrm{KW}$ turbines was, respectively, $0.039 \%$ and $0.043 \%$. The data used in this study was gathered from 16 weather stations spread across Spain. The information was used to assess AMM's capability in estimating power density. The results of this study indicate that the average absolute error of AMM and MLH are $3.47 \%$ and $10.59 \%$, respectively. To minimize unreliability in a wind energy evaluation, the wind characteristics, wind power density, and wind turbine energy generation rates must be calculated optimally. Therefore, using an accurate method for parameter estimation will reduce the unreliability factor (Akdağ \& Güler, 2018).

Rehman, Natarajan, Vasudevan, and Alhems (2020) investigated wind power potential in three cities at different heights and differing distances from the coastline in the Tamil Nadu State of India. In this study, wind sources were analyzed and described statistically by using data gathered across 38 years through a 2-parameter Weibull distribution function. The daily, monthly, and yearly changes in wind speed were scrutinized and the most probable and maximum wind speed energy, wind energy production, and capacity factor were also analyzed. The average wind speed recorded in the city of Chennai was $5.4 \mathrm{~m} / \mathrm{s}$, while in Erode and Coimbatore it was $4.34 \mathrm{~m} / \mathrm{s}$ and $4.7 \mathrm{~m} / \mathrm{s}$, respectively. The average maximum wind speed in the three cities was $21.42 \mathrm{~m} / \mathrm{s}, 13.97 \mathrm{~m} / \mathrm{s}$, and $15.50 \mathrm{~m} / \mathrm{s}$, respectively. The highest figure was recorded in Chennai as it is located near the coastline, while the average wind speeds in the inland cities were lower. The average wind power density for the cities of Chennai, Erode, and Coimbatore were, respectively, $192 \mathrm{~W} / \mathrm{m} 2,76 \mathrm{~W} / \mathrm{m} 2$, and $97 \mathrm{~W} / \mathrm{m} 2$, and the yearly energy contents of the same three cities were $1127 \mathrm{kWh} / \mathrm{m} 2,666 \mathrm{kWh} / \mathrm{m} 2$, and $849 \mathrm{kWh} / \mathrm{m} 2$, respectively. The wind directions are mostly from north to east and south to west in Chennai, from west to south and west to north in Erode, and from the west and west to south in Coimbatore. As a result, Chennai possesses the most optimal peripheral characteristics for wind energy development, followed by Coimbatore. The city of Erode, however, has the lowest prospects for the establishment of a wind energy production site. In terms of density, Chennai has a higher average of wind power mainly as it is located close to the coastline and sits at the lowest altitude above average sea level. Although both Coimbatore and Erode are inland, Coimbatore's higher altitude makes its average wind power density higher than that of Erode (Rehman et al., 2020).

Sohrab et al. (2019), in their futuristic study, developed scenarios for wind energy and its estimated employment in Iran in 2050. With respect to the lack of long-term policies and plans to make use of wind energy, this study was carried out to calculate the employment rate resulting from wind energy use in Iran. To this end, three scenarios were designed. The below scenarios were created for the year 2050 according to the government's goal in the Sixth Development Plan which involves supplying 5\% of country's electrical energy requirements in the year 2021 through renewable sources, in which the share of wind energy is about $50 \%$.

- The low scenario: Supplying $2.5 \%$ of the country's electricity (61.5 GW).

- The medium scenario: Supplying $5 \%$ of the country's electricity (122 GW).

- The high scenario: Supplying $10 \%$ of the country's electricity (244GW) (Sohrab et al., 2019).

Nazir et al. (2020) carried out an extensive and productive investigation concerning wind forecasting methods and using Artificial Neural Networks (ANNs). An ANN is an instrument used to measure wind absorption that is investigated and analyzed in most studies. Methods based on an ANN are also utilized in designing wind models and detecting and controlling system faults. Generally, the so-called methods are used in conditions where forecasting is highly necessary. This investigation has expanded the previous related studies and focuses on a variety of outlooks 
in forecasting wind energy. The available databases are used as main sources of previously published documents. The results of the investigation highlight the capabilities of hybrid systems to combine the methods which significantly elevate the accuracy of wind-based energy estimation. With regards to the ANN methods used in this study, the producers will be able to autonomously choose the most suitable model for any condition based on a wide range of ANN methods for any specific purposes and needs. It seems that a combination of ANN methods is beneficial for various applications in that ANN-based methods can be combined with a variety of instruments and consequently exploit the benefits of hybrid systems (Nazir et al., 2020).

Amarasinghe and Perera (2021) conducted a study which showed that the conditions in Sri Lanka's are reasonably suitable for using wind energy. However, only certain locations are optimal for the construction of wind farms as the wind potential is strongly connected to several geographic factors. This study introduced spatial approaches to determine potential areas for wind farms and extracted five decision-making factors from the existing geographical databases. The factors are altitude, wind density, land use, restricted area, and adjacency to communication paths and roads. The relative capacity of these factors was estimated through spatial MCDM in a GIS environment. The results of the study concluded that Sri Lanka has sufficient wind capacity in $20 \%$ of its lands, approximately $13,130 \mathrm{~km}^{2}$, to maximize the renewable energy share in the country's national power supply. Most potential locations were identified to be on the coastal belts with low population levels. It is also recommended that more wind farms be established and installed so that more than half the capacity of renewable energy could be exploited until 2030 for the production of electricity (Amarasinghe \& Perera, 2021).

Al-Yahyai and Charabi (2015) chose Duqm city in Oman for their investigation in which they measured the wind energy potential through simulating a $25 \mathrm{MW}$ wind power plant by using WAsP and relying on the annual wind energy figures. The results of their simulation indicated that the city of Duqm has a high wind potential and that constructing and using wind farms can be very productive in that city. The area's wind power density is between 200 and $800 \mathrm{~W} / \mathrm{m}^{2}$ at a height of 80 meters. Also, Duqm has a constant wind flow that could meet power requirements during peak hours or afternoons. The capacity of this simulated windfarm is approximately 75 GWh (Al-Yahyai \& Charabi, 2015).

Luankaeo and Tirawanichakul (2017) conducted a study in which they measured wind energy potential, at a height of 30 meters, in the Khorhong area in Songkhla province, Thailand. Wind direction and speed were scrutinized in this research. Wind and weather data were analyzed through WAsP. It was understood that around Hat Yai campus, wind speed was $8.6 \mathrm{~m} / \mathrm{s}$ and that the average wind power density was $98 \mathrm{~W} / \mathrm{m}^{2}$. The wind direction was from north to east (Luankaeo \& Tirawanichakul, 2017).

Arreyndip, Joseph, and David (2016) studied the wind energy potential of Kribi, Douala, and Limbe, three of Cameroon's coastal cities, for the purpose of constructing a wind power plant. The estimation of wind energy potential was carried out through considering the data related to the average monthly wind statistics across a 31-year period and comparing the data with Weibull parameters. The wind power densities of Kribi, Douala, and Limbe were 25.42 $\mathrm{W} / \mathrm{m}^{2}, 8 \mathrm{~W} / \mathrm{m}^{2}$, and $33.7 \mathrm{~W} / \mathrm{m}^{2}$, respectively. Kribi's maximum wind speeds were $2.42 \mathrm{~m} / \mathrm{s}$ and $3.35 \mathrm{~m} / \mathrm{s}$, Limbe's were $2.27 \mathrm{~m} / \mathrm{s}$ and $3.03 \mathrm{~m} / \mathrm{s}$, and Duala's were $1.67 \mathrm{~m} / \mathrm{s}$ and $2 \mathrm{~m} / \mathrm{s}$. As the data showed, wind speed averages were low in all three cities at a rate below $4 \mathrm{~m} / \mathrm{s}$. It was concluded that since the wind speed was not high enough in these areas, constructing wind farms and generating electricity through wind turbines may not be meaningfully effective for the purpose of power production. Therefore, to achieve more productive results, solar energy is recommended to be used along with wind energy (Arreyndip et al., 2016).

Okeniyi, Moses, and Okeniyi (2015) carried out a study in which they investigated the daily wind speed averages of the Akure area in Ondo state, Nigeria by analyzing local data gathered across 11 years through Weibull and Rayleigh distribution methods. According to their observations, the monthly average wind speed was between 1.41 $\mathrm{m} / \mathrm{s}$ and $4.24 \mathrm{~m} / \mathrm{s}$. Furthermore, the same figures through Rayleigh estimations were found to be between 1.40 and $4.16 \mathrm{~m} / \mathrm{s}$. The overall results of wind speed measured through Weibull and Rayleigh were $2.71 \mathrm{~m} / \mathrm{s}$ and $2.70 \mathrm{~m} / \mathrm{s}$, 
respectively. The value for the average of wind power density was estimated to be $18.51 \mathrm{~W} / \mathrm{m}^{2}$ through Weibull, and for Rayleigh the figure was found to be $22.26 \mathrm{~W} / \mathrm{m}^{2}$. It was concluded that to harvest wind power into electricity, wind turbines capable of operating in low wind speeds needed to be installed and used in this area (Okeniyi et al., 2015).

Premono, Tjahjana, and Hadi (2017) conducted a statistical investigation of wind speed characteristics and measured wind speed potentials of the northern coast of Semarang in Java, Indonesia. The annual wind data was gathered from weather stations at a height of ten meters. Furthermore, wind potential was measured through the Weibull distribution function. The measured wind speed was $5.32 \mathrm{~m} / \mathrm{s}$, the maximum annual wind speed was 6.45 $\mathrm{m} / \mathrm{s}$, and the wind power density rate was $103.87 \mathrm{~W} / \mathrm{m}^{2}$. Suitable wind turbines were selected in the simulations in this study. The results showed that the capacity coefficient of these simulated turbines was $29.79 \%$ and their production capacity was $261 \mathrm{MWh}$ /year (Premono et al., 2017).

Fazelpour et al. (2015) studied wind potential in the cities of Tabriz and Ardabil in Iran. They used the Weibull distribution function. Using the data gathered from weather stations, measurements made in three-hour intervals at a height of ten meters across one year were scrutinized. The Weibull parameter in Tabriz was from 3.35 to $4.45 \mathrm{~m} / \mathrm{s}$, with an average of $4.18 \mathrm{~m} / \mathrm{s}$.

The corresponding value for Ardabil was from 3.68 to $4.55 \mathrm{~m} / \mathrm{s}$, with an average of $4.16 \mathrm{~m} / \mathrm{s}$. The results indicate that the highest potential months for wind energy in Tabriz are July and August, and for Ardabil, the consecutive months of September and October carry the highest potential. It can be understood from the results that utilizing wind turbines in these two cities could be quite worthwhile (Fazelpour et al., 2015).

Allouhi et al. (2017) studied the wind energy potential in six areas within the kingdom of Morocco, comprising Al Hoceima, Tetouane, Assila, Essouira, Laayoune, and Dakhla. To meet their needs, they used Weibull distribution's parameters, and carried out the necessary statistical analysis based on wind speed and direction. The wind characteristics were estimated through WAsP methods.

Furthermore, wind data was collected across a five-year period at heights of 50 and 70 meters. The daily and yearly wind speed average for Laayoune and Dakhla at 50 meters were 7 and $6.5 \mathrm{~m} / \mathrm{s}$, respectively. The daily and monthly wind speed averages for the other areas were between 3 and $6 \mathrm{~m} / \mathrm{s}$ It was concluded that these potential for wind power utilization in these areas is quite reasonable, however, more research needs to be done for a final decision to be made (Allouhi et al., 2017).

\subsection{Damghan City}

Damghan is a city in Semnan province and its center is a town with the same name, Damghan. It includes the two suburban areas of Markazi and Amir abad. Damghan covers an area of $12,110 \mathrm{~km}^{2}$ and is located $1,170 \mathrm{~m}$ above sea level. According to the census, the population of this city in 2016 was 94,190. The northern and southern neighbors of Damghan are Mazandaran province and Isfahan province, respectively. From the east, it has borders with the city of Shahroud, and from the west it is neighbors with the cities of Semnan and Mahdi Shahr (Mirhosseini, Sharifi, \& Sedaghat, 2011).

Strong north winds and rainfall resulting from winds blown from the Gorgan and Mazandaran areas make the climate of Damghan cold during winter and mild through the summer. Semnan City, however, has hot summers and mild winters. Shahroud city has cold northern areas, mild central areas, and hot southern parts. Garmsar city, in a dry, desert area, has very hot summers and its winters are quite cold and rainy. The city of Damghan, located between the middle heights of the Alborz range and the Kavir desert Figure 3, has diverse climatic conditions including humid, dry, and ultra-dry. Low levels of precipitation, night and day temperature disorders, and a long, dry season of between seven and nine months are among the feature climatic characteristics of this city. 


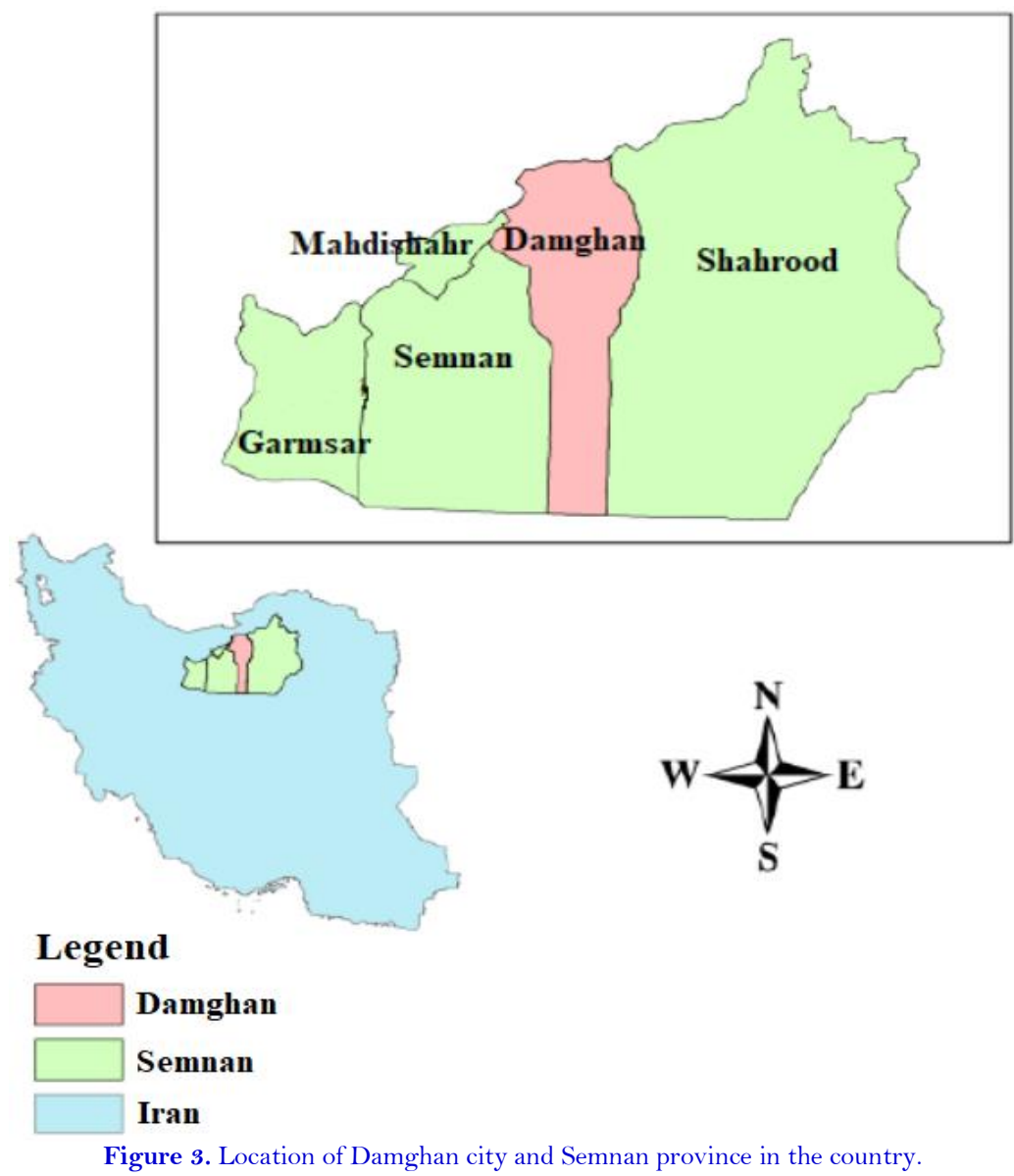

Because of its natural conditions and latitude, Damghan city is effectively under the influence of western rain systems. Rainfall and changes in the compression system of this area usually begin during late September and continue until mid-spring. The northern part of Damghan city is under the double influence of mountain rainfalls originating in Mazandaran province. The precipitation rate decreases from north to south, however, there is a rise in this figure from east to west. The annual rainfall rate has constantly been lower that $400 \mathrm{~mm}$. The highest rate of seasonal precipitation occurs during winter at $51.2 \mathrm{~mm}$, while the lowest levels of rainfall are in the summer season at $5.8 \mathrm{~mm}$. March has generally been the month with the highest rainfall rate of $24 \mathrm{~mm}$, while the lowest amount of rainfall has constantly occurred during the month of August at an average rate of $1.5 \mathrm{~mm}$. Reports from Damghan's weather station suggest that the minimum 24-hour rainfall rate is $20.6 \mathrm{~mm}$ on average, and the maximum average precipitation rate is $50 \mathrm{~mm}$. The average frostiest days have been maximum during January (28 days), and minimum during September and March, with only one day of extreme cold. The gap between the first fall season frost and the last spring frost is approximately five months which indicates the plant growth period.

Damghan city has diverse climatic sub-divisions from north to south. In its northernmost territory, a limited range has a humid climate, the southern and middle territories, however, have a sub-humid range. The mild to moderate, semi-arid climate expands from the northern to the western parts of the city. The area between the moderate semi-arid and central arid climates is separated by an extreme semi-arid climate. The dry climate of the middle territory is home to the main and central villages of the area. A climatic unit comprised of semi-humid and extreme semi-arid climatic conditions exist within the more southern latitudes and boundaries of each middle part of the city. The whole southern territory of the city is, however, covered in an ultra-arid climate, making it unsuitable for living in or for any industrial activity.

According to climate pattern classifications, the city of Damghan is considered to be arid. Such a climate has features including a low annual precipitation level of about 127mm, an average annual temperature of 15.1 degrees 
centigrade, high fluctuations in daytime and nighttime temperatures, irregular rainfall (higher rates during the winter and lower rates during the summer), high evaporation rates of about 2,000mm, and frosty days from late October to mid-March. The annual average temperature of Damghan city is 15.1 degrees centigrade, and its average temperature highs and lows, annually, are 21.8 and 8.7 degrees centigrade, respectively. The absolute maximum average temperature is 42 degrees, while the absolute minimum yearly average is -16.5 degrees. The amplitude of circadian temperature changes, which is calculated through the summation of the average annual minimum and maximum, is approximately 13.1 degrees. The average seasonal temperature in a year in Damghan city is at its maximum during summer at 25.7 degrees and the lows occur in the winter season with an average of 4.8 degrees. The average temperatures in fall and spring are, respectively, 9.8 and 20.6 degrees centigrade. The average relative humidity of the city of Damghan are, respectively, $44 \%$ and $55 \%$ during October and November, $66 \%$ in December, and $68 \%$ in January. In other words, this figure experiences a steady upward trend from early fall to mid-winter and the trend sees a reversal from February through the end of the summer season. The average relative humidity of February and March are $64 \%$ and 52\%, respectively. The lowest figures of $32 \%$ and $33 \%$ are found during May, June, July, August, and September, which is indicative of the driest months in the city of Damghan.

The Ghods Cycled power plant of Semnan, also known as the Shahid Bakeri power plant, is located at $10 \mathrm{~km}$ from the Semnan highway and started operating in January 2012. The production capacity is 484MW comprised of two 162MW gas units of V94.02 type, and one 160MW steam unit, all in 100 hectares of land. The current capacity of the power plant is $324 \mathrm{MW}$, since the steam and combined cycle sections have not been put into operation as yet. The power plant is mainly fueled by natural gas and its backup fuel is gasoline (Hafeznia, Pourfayaz, \& Maleki, 2017).

\subsection{Electricity Production and Consumption in Damghan City}

Overall, 2,060MWh of electricity was produced in Damghan in 2020. This has met the needs of 395,261 consumers in different commercial, industrial, agricultural, home, and public uses. Currently, all the electricity requirements of Damghan city are provided by the newly constructed thermal power plants that use gas as their main source of fuel.

Based on the high capacity of Damghan city, one of the most satisfying solutions to combat the problem of low electricity supplies is to use the free energy of wind. Therefore, the rest of this article will investigate the probability of constructing wind farms in the city of Damghan by clarifying the necessary criteria for building such power plants, which in turn will result in the identification of suitable locations for that purpose.

\section{DETERMINING THE EFFECTIVE CRITERIA FOR SELECTING A WIND POWER PLANT LOCATION}

The common techniques for determining a location for industrial sites and the experiences gathered from applying the GIS along with multi-criteria decision-making indicate that selecting an appropriate location for a wind farm is greatly reliant on a comprehensive understanding of the effective criteria. Disregarding any underlying factors might result in the selection of an inappropriate location which can, in turn, lead to huge damage and loss.

The construction and operation of a wind power plant requires the allocation of a large budget and a considerable amount of time and energy, therefore, the precise determination of a suitable location can alleviate unnecessary costs. The selected site must be of high environmental potential and efficiency and the land should be strong enough to withstand the construction of the necessary structures. For instance, the construction of a power plant on fault lines, swamps, land with loose soil, or any location prone to subsidence must be avoided at all costs. The selection must also consider the safety of the location and powerhouse against any possible natural disasters like earthquakes or floods. General hygiene, natural resources, and wildlife should not be put at risk by the construction and operation processes in the chosen area. The construction of a powerhouse also has either advantageous or detrimental social and cultural impacts that should be considered when determining a location. 
Table 2. Effective criteria in selecting a suitable location for the construction of a wind farm.

\begin{tabular}{|c|c|c|c|c|}
\hline Criterion type & Criterion name & $\begin{array}{l}\text { Criterion } \\
\text { size }\end{array}$ & $\begin{array}{l}\text { Layer merging } \\
\text { method }\end{array}$ & Reference \\
\hline \multirow{9}{*}{$\begin{array}{l}\text { Techno- } \\
\text { economic }\end{array}$} & $\begin{array}{l}\text { Minimum and maximum } \\
\text { distance from main pathways }\end{array}$ & $\begin{array}{l}2,500 \text { meters } \\
-40 \mathrm{Km}\end{array}$ & Fuzzy & $\begin{array}{l}\text { (Al-Yahyai \& Charabi, 2015; } \\
\text { Amarasinghe \& Perera, 2021; } \\
\text { El Khchine et al., 2019; } \\
\text { Moradi et al., 2020; Nazir et } \\
\text { al., 2020; Rehman et al., 2020) }\end{array}$ \\
\hline & $\begin{array}{l}\text { Minimum and maximum } \\
\text { distance from detours }\end{array}$ & $\begin{array}{l}500 \text { meters - } \\
40 \mathrm{Km}\end{array}$ & Fuzzy & $\begin{array}{c}\text { (Abdel-Basset, Gamal, } \\
\text { Chakrabortty, \& Ryan, 2021; } \\
\text { Amarasinghe \& Perera, 2021; } \\
\text { El Khchine et al., 2019; } \\
\text { Luankaeo \& Tirawanichakul, } \\
\text { 2017; Okeniyi et al., 2015; } \\
\text { Rehman et al., 2020) }\end{array}$ \\
\hline & $\begin{array}{lcr}\text { Minimum } & \text { and } & \text { maximum } \\
\text { distance } & \text { from } & \text { power } \\
\text { transmission lines } & \end{array}$ & $\begin{array}{l}250 \text { meters - } \\
30 \mathrm{Km}\end{array}$ & Fuzzy & $\begin{array}{c}\text { (Allouhi et al., 2017; } \\
\text { Arreyndip et al., 2016; } \\
\text { Hafeznia et al., 2017; } \\
\text { Mirhosseini et al., 2011) }\end{array}$ \\
\hline & $\begin{array}{l}\text { Minimum distance from } \\
\text { railways }\end{array}$ & 250 meters & Boolean & $\begin{array}{c}\text { (El Khchine et al., 2019; } \\
\text { Mahdy \& Bahaj, 2018; Moradi } \\
\text { et al., 2020) }\end{array}$ \\
\hline & $\begin{array}{l}\text { Minimum distance from military } \\
\text { airports }\end{array}$ & $\begin{array}{l}15, \mathrm{OOO} \\
\text { meters }\end{array}$ & Boolean & $\begin{array}{l}\text { (Hafeznia et al., 2017; } \\
\text { Premono et al., 2017) } \\
\end{array}$ \\
\hline & $\begin{array}{l}\text { Minimum distance from local } \\
\text { airports }\end{array}$ & 2,500 meters & Boolean & $\begin{array}{l}\text { (El Khchine et al., 2019; } \\
\text { Hafeznia et al., 2017; Moradi } \\
\text { et al., 2020; Nazir et al., 2020; } \\
\text { Rehman et al., 2020) }\end{array}$ \\
\hline & $\begin{array}{l}\text { Minimum distance from oil and } \\
\text { gas pipelines }\end{array}$ & 500 meters & Boolean & (Moradi et al., 2020) \\
\hline & $\begin{array}{l}\text { Minimum distance from } \\
\text { telecommunication lines }\end{array}$ & 500 meters & Boolean & (Moradi et al., 2020) \\
\hline & $\begin{array}{l}\text { Wind speed and wind class } \\
\text { choice }\end{array}$ & $\begin{array}{l}\text { More than } \\
5.5 \mathrm{~m} / \mathrm{s}\end{array}$ & Fuzzy & $\begin{array}{c}\text { (Arreyndip et al., 2016; Mahdy } \\
\text { \& Bahaj, 2018; Mirhosseini et } \\
\text { al., 2011) }\end{array}$ \\
\hline \multirow[t]{2}{*}{ Geographic } & $\begin{array}{l}\text { Maximum distance from sea } \\
\text { levels }\end{array}$ & 2,000 meters & Fuzzy & $\begin{array}{c}\text { (Hafeznia et al., 2017; Mahdy } \\
\text { \& Bahaj, 2018; Moradi et al., } \\
\text { 2020; Okeniyi et al., 2015) }\end{array}$ \\
\hline & $\begin{array}{l}\text { The maximum percentage of } \\
\text { land slope }\end{array}$ & $15 \%$ & Fuzzy & (Premono et al., 2017) \\
\hline \multirow{14}{*}{ Environmental } & Minimum distance from cities & 2,000 meters & Boolean & $\begin{array}{l}\text { (Arreyndip et al., 2016; } \\
\text { Moradi et al., 2020) }\end{array}$ \\
\hline & Minimum distance from villages & 500 meters & Boolean & $\begin{array}{l}\text { (Arreyndip et al., 2016; Mahdy } \\
\text { \& Bahaj, 2018; Moradi et al., } \\
\text { 2020) }\end{array}$ \\
\hline & $\begin{array}{l}\text { Minimum distance from } \\
\text { individual houses }\end{array}$ & 500 meters & Boolean & $\begin{array}{c}\text { (Allouhi et al., 2017; Premono } \\
\text { et al., 2017) }\end{array}$ \\
\hline & $\begin{array}{l}\text { Minimum distance from } \\
\text { industrial areas }\end{array}$ & 250 meters & Boolean & (Moradi et al., 2020) \\
\hline & $\begin{array}{l}\text { Minimum distance from main } \\
\text { and minor faults }\end{array}$ & 1,000 meters & Boolean & (Hafeznia et al., 2017) \\
\hline & $\begin{array}{l}\text { Minimum distance from reverse } \\
\text { faults }\end{array}$ & 2,000 meters & Boolean & (Hafeznia et al., 2017) \\
\hline & Minimum distance from ponds & 500 meters & Boolean & $\begin{array}{l}\text { (Arreyndip et al., 2016; } \\
\text { Moradi et al., 2020) }\end{array}$ \\
\hline & Minimum distance from rivers & 500 meters & Boolean & $\begin{array}{l}\text { (Hafeznia et al., 2017; } \\
\text { Premono et al., 2017) }\end{array}$ \\
\hline & $\begin{array}{l}\text { Minimum distance from seas and } \\
\text { lakes }\end{array}$ & 500 meters & Boolean & $\begin{array}{l}\text { (Mirhosseini et al., 2011; } \\
\text { Moradi et al., 2020; Okeniyi et } \\
\text { al., 2015) }\end{array}$ \\
\hline & $\begin{array}{l}\text { Minimum distance from } \\
\text { coastlines }\end{array}$ & 500 meters & Boolean & $\begin{array}{c}\text { (Allouhi et al., 2017; Okeniyi } \\
\text { et al., 2015; Premono et al., } \\
2017) \\
\end{array}$ \\
\hline & Minimum distance from mines & 100 meters & Boolean & (Mirhosseini et al., 2011) \\
\hline & Minimum distance from dams & 100 meters & Boolean & (Mirhosseini et al., 2011) \\
\hline & Minimum distance from jungles & 200 meters & Boolean & $\begin{array}{c}\text { (Luankaeo \& Tirawanichakul, } \\
2017 \text {; Okeniyi et al., 2015) }\end{array}$ \\
\hline & Minimum distance from gardens & 50 meters & Boolean & (Mirhosseini et al., 2011) \\
\hline
\end{tabular}




\begin{tabular}{|c|c|c|c|c|}
\hline Criterion type & Criterion name & $\begin{array}{l}\text { Criterion } \\
\text { size }\end{array}$ & $\begin{array}{l}\text { Layer merging } \\
\text { method }\end{array}$ & Reference \\
\hline & $\begin{array}{l}\text { Minimum distance from } \\
\text { historical areas }\end{array}$ & 1,000 meters & Boolean & (Premono et al., 2017) \\
\hline & Minimum distance from springs & 200 meters & Boolean & (Mirhosseini et al., 2011) \\
\hline & Minimum distance from caves & 200 meters & Boolean & (Allouhi et al., 2017) \\
\hline & $\begin{array}{l}\text { Minimum distance from flood } \\
\text { routes }\end{array}$ & 500 meters & Boolean & (Allouhi et al., 2017) \\
\hline & $\begin{array}{l}\text { Minimum distance from } \\
\text { protected areas }\end{array}$ & 2,000 meters & Boolean & $\begin{array}{l}\text { (Al-Yahyai \& Charabi, } 2015 \text {; } \\
\text { Allouhi et al., 2017; Arreyndip } \\
\text { et al., 2016; Premono et al., } \\
\text { 2017) }\end{array}$ \\
\hline
\end{tabular}

The establishment of such a facility has the strength to spin the wheels of many large and small industries; it also can create an abundance of long-term job opportunities, so the local rate of unemployment can also be considered. However, such factors cannot be regarded as essential when compared when other underlying elements like grid lines and communication paths. This study makes an effort to describe these effective criteria. The research is carried out throughout the province under the scale of 1:25000. Making use of a framework like GIS can provide a solid base on which to apply the aforementioned factors of choosing an appropriate location. According to the investigations of the applied factors under the scale of 1:25000, the below criteria are used for the determination of the location of a winddriven power plant in Semnan province. These criteria are specific for the conditions of Semnan province, however, with minor alterations, they can be used in other parts of the country. The effective role of each criterion along with the reason for their selection are explained below.

Various scientific studies have investigated the criteria and parameters required for the establishments of winddriven power plants in environmental, geographical, ecological, demographic, land functionality, hydrological, security, and technical aspects and categories. However, since some of these groups have a considerable overlap with other categories and are sometimes more comprehensive than others, this study will consider the three groups of environmental, techno-economic, and geographical criteria for the depiction, investigation, and thematic classification of the criteria. The environmental criteria should ensure a minimum distance is maintained from protected areas, those controlled by the department of environment, jungles, lakes, and rivers. The techno-economic criteria involving the establishment of a wind-driven power plant include the selection of turbine type according to the wind speed in line with turbine specifications and IEC-61400 standards, the distance of the site from communication paths like detours, expressways, and highways, the distance between the proposed power plant and railways, local, and military airports, and power transmission lines in the area. The geographical criteria under investigation include the maximum height from the sea and the maximum percentage of land slope. The list of all the effective criteria in determining a suitable location for the establishment of a wind-driven power plant is provided in Table 2. The table shows all three selected criteria along with the size of each one and the method by which each is integrated with the others.

\section{LAYER PROCESSING AND MAP PREPARATION}

The performance and role of the criteria mentioned in Table 2 can vary in the process of selecting a location for wind-driven power plant. Various layers of data are required to be prepared with respect to the nature and role of the criteria within this process. The integration of these informational layers with one another can involve complicated procedures which makes the merging of layers demanding.

To merge the criteria mentioned in Table 2 more precisely and to avoid the impact of a layer overlapping another layer, the criteria are classified into two types of restriction and fuzzy. First, the layers of information existing in the restriction class are integrated with each other using the Boolean method. Next, the other layers can then create the fuzzy map once they are fuzzified and their weights are considered individually. Lastly, by combining the fuzzy and restriction maps, the final map is created. A thorough description of the process is included below. 


\subsection{Restrictions Analysis and Creating the Restriction Map}

The restriction map, which depicts the inappropriate locations for construction in the area under investigation (according to national, local, or international laws and regulations), has been created by merging the criteria shown in Table 2 under the Boolean method with the same coefficients Figure 4. Based on the restriction map, from the entire 14,000 $\mathrm{Km}^{2}$ of the Damghan city area, about 1,500 $\mathrm{Km}^{2}$ are considered inappropriate for the construction of wind farms according to the above criteria. This equates to $10.7 \%$ of the whole Damghan city area. In the below map, the blue areas do not have primary environmental and technical problems for the establishment of wind farms, and the omitted areas in white illustrate inappropriate construction locations.

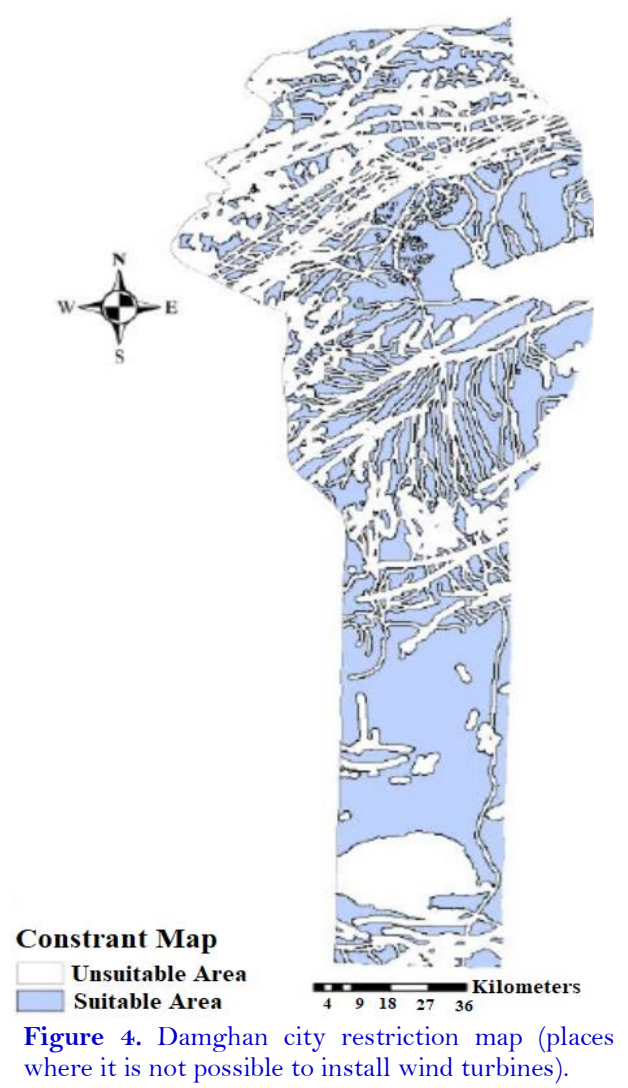

The restriction map alone is of little use since it only depicts the locations on which the construction of wind farms is allowed by law, but it does not consider the suitability of the locations. In addition, the remaining areas do not share the same construction value and some are more qualified than others. Therefore, by utilizing fuzzy logic and considering the layers that are explained below, each layer will at first be fuzzified and then the layers which have been fuzzified will be given weight by the use of the AHP method. Thereafter, by merging these layers, the fuzzy map will be developed. The final map will be prepared by mixing the fuzzy and restriction maps showing the suitable locations for constructing wind-driven power plants in the area.

\subsection{Development of Factor Maps and the Fuzzification of Layers}

Because the restriction map is of no use by itself, for a more optimal and much more precise decision-making process, the fuzzy maps of other criteria have been prepared. These criteria include power transmission lines, height from sea level, land slope, and wind speed. In this article, the factor maps are developed in a way that the amount of each pixel will not only indicate the relative importance of each factor map but will also represent the relative significance of each class from within any specified factor map. This amount is a number between 0 and 1 . The determination of the degree of membership is carried out through appropriate mathematical functions. Fuzzy 
functions have been used in Equations 1 to 5 and the maps created on their basis are shown in Figures 5 to 9 (Mahdy $\&$ Bahaj, 2018).

$0 \quad \mathrm{x}<500$

$$
\mu_{x}=\left\{\frac{1}{2}\left(1+\cos \left(\pi\left(\frac{X-500}{4000-500}\right)\right)\right) 500 \ll x \ll 4000\right.
$$

$0 \quad \mathrm{x}>4000$

$0 \quad \mathrm{x}<250$

$$
\mu_{x}=\left\{\frac{1}{2}\left(1+\cos \left(\pi\left(\frac{X-250}{3000-250}\right)\right)\right) 250 \ll x \ll 3000\right.
$$

$0 \quad \mathrm{x}>3000$

$$
\mu_{x}=\left\{\frac{1}{2}\left(1+\cos \left(\pi\left(\frac{X-2000}{2000}\right)\right)\right) 0 \ll x \ll 2000\right.
$$

$\mathrm{O} \quad \mathrm{x}>2000$

$$
\mu_{x}=\left\{\frac{1}{2}\left(1+\cos \left(\pi\left(\frac{X-15}{15}\right)\right)\right) 0 \ll x \ll 15\right.
$$

$$
\mathrm{O} \quad \mathrm{x}>15
$$

$0 \quad \mathrm{x}<4.1$

$$
\begin{aligned}
& \mu_{x}=\left\{\frac{1}{2}\left(1+\cos \left(\pi\left(\frac{X-4.1}{5.5-4.1}\right)\right)\right) \quad 4.1 \ll \mathrm{x} \ll 5.5\right. \\
& \left\{\frac{1}{2}\left(1+\cos \left(\pi\left(\frac{X-4.1}{5.5-4.1}\right)\right)\right) \quad 5.5 \ll \mathrm{x}<12\right. \\
& x>>12
\end{aligned}
$$

$0 \quad \mathrm{x}>>12$

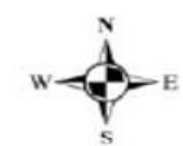

Fuzzy Roads Map
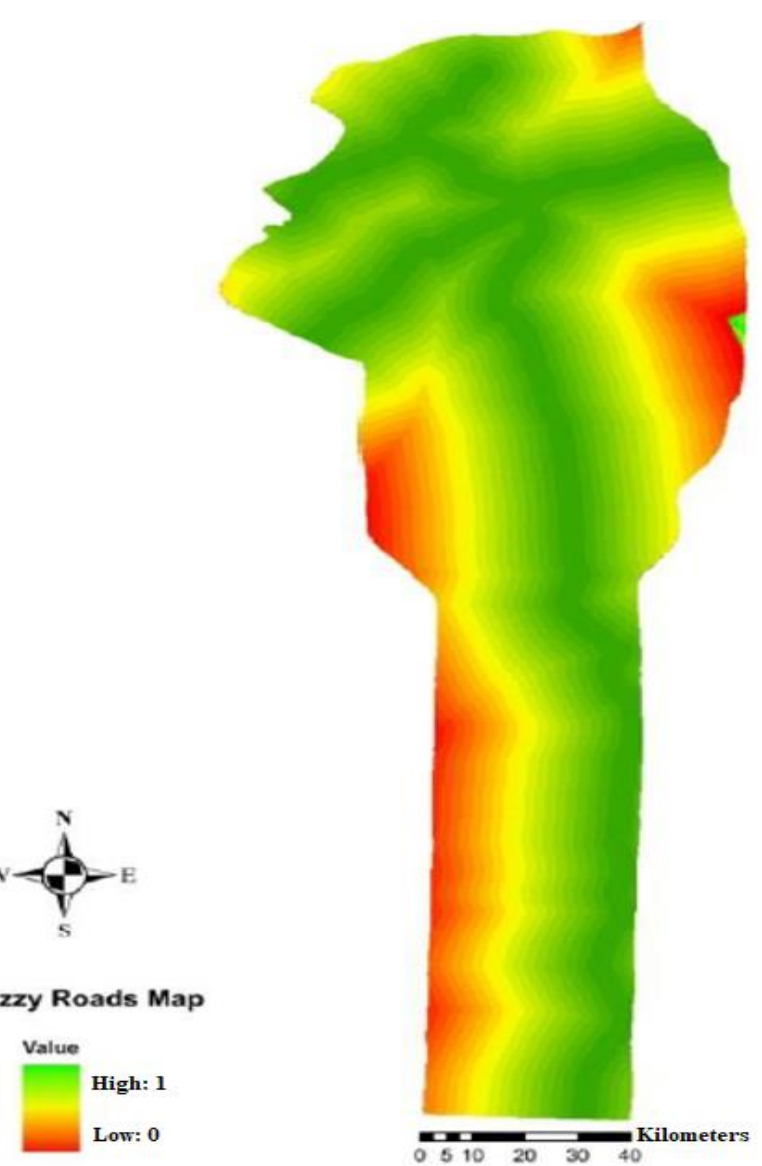

Figure 5. Fuzzy maps of Damghan city - fuzzy map of Damghan city access roads. 


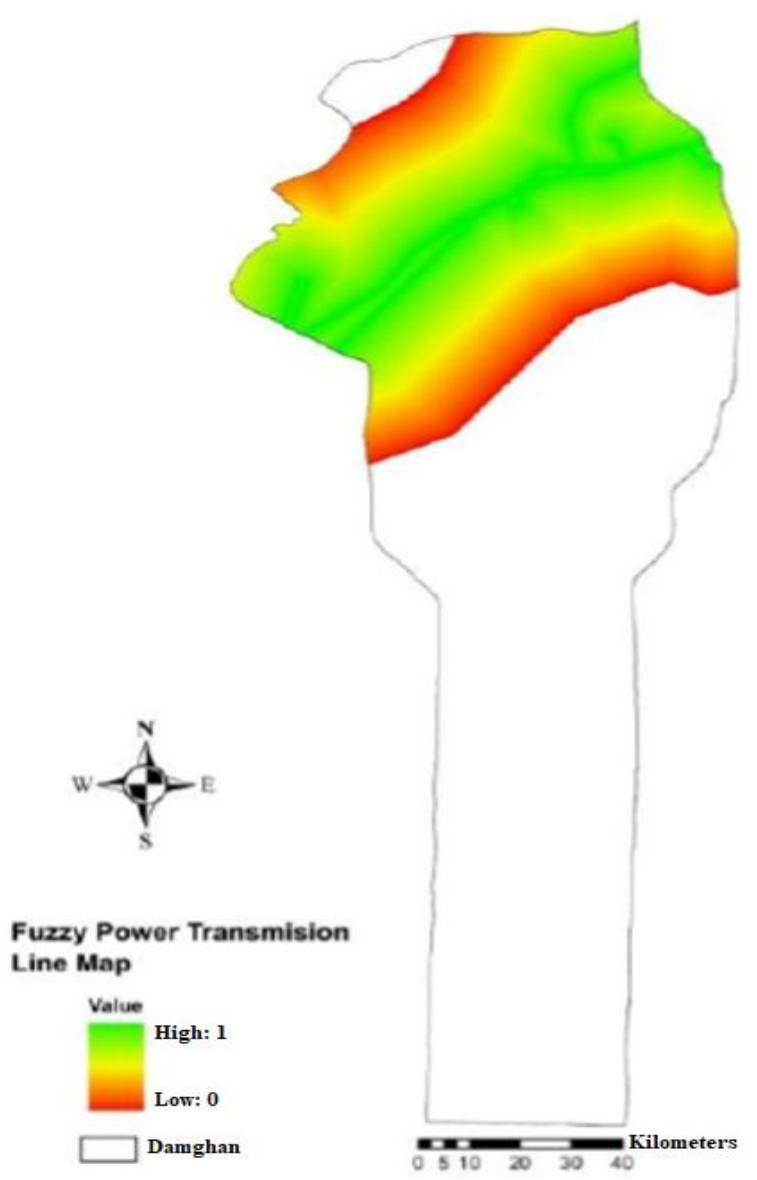

Figure 6. Fuzzy maps of Damghan city - fuzzy map of city power transmission lines.

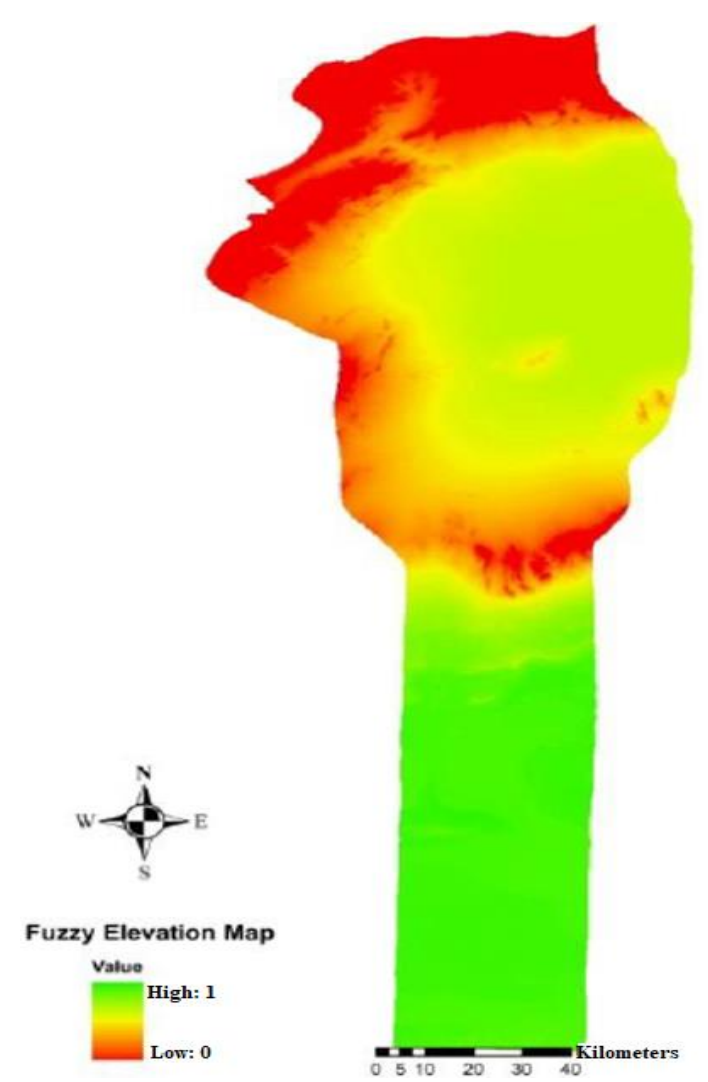

Figure 7. Fuzzy maps of Damghan city - fuzzy map of land height in Damghan city. 


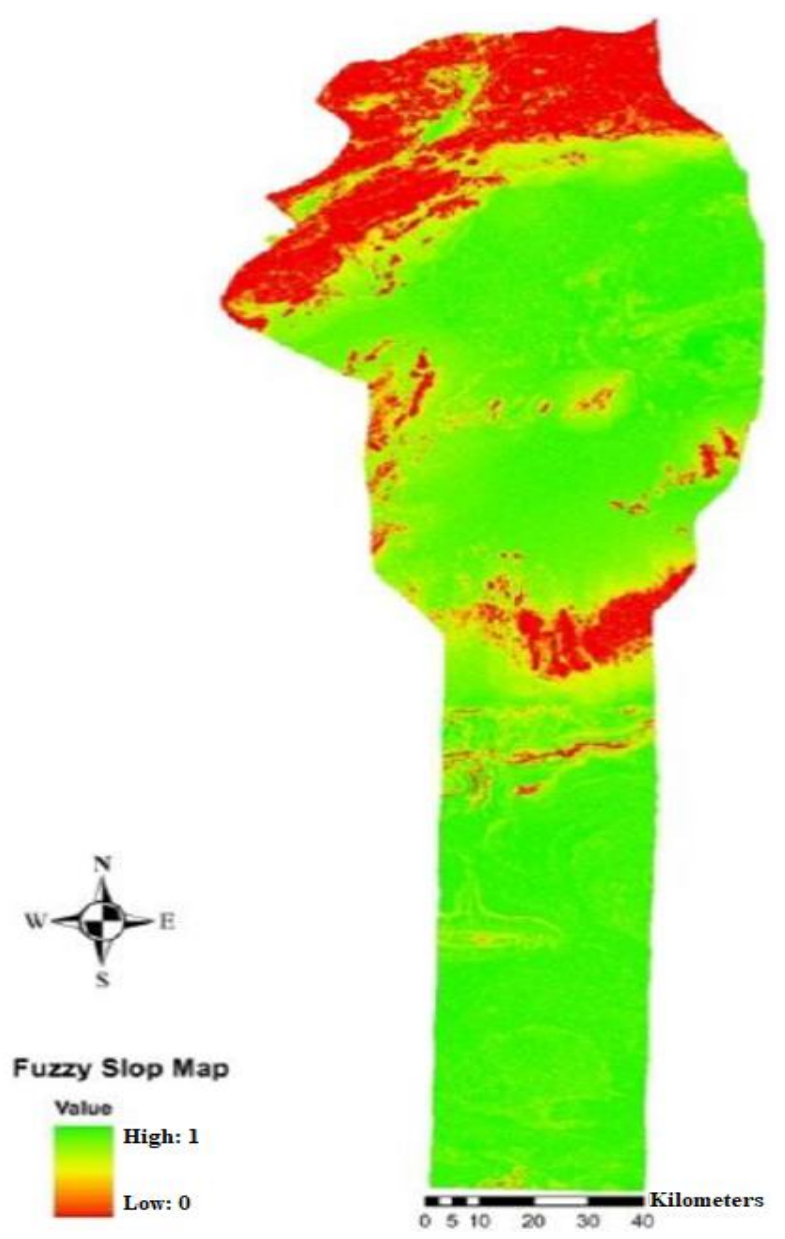

Figure 8. Fuzzy maps of Damghan city - fuzzy map of land slope in Damghan city.
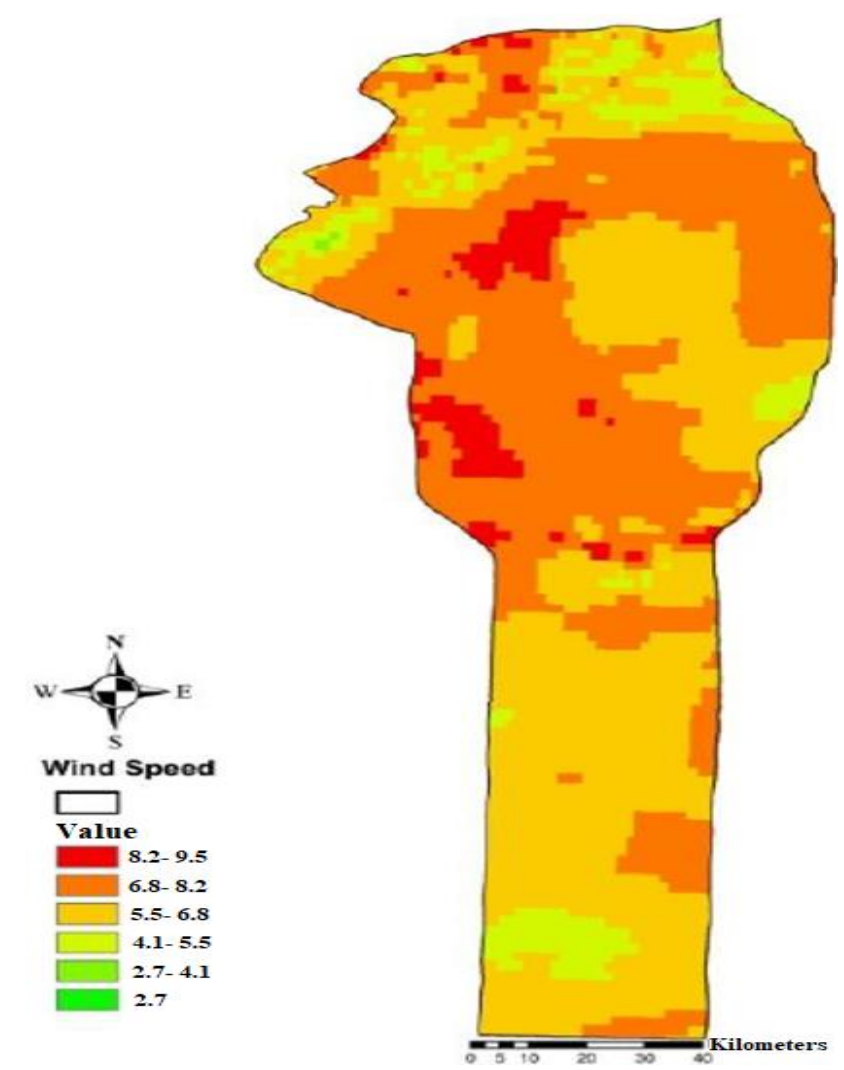

Figure 9. Fuzzy maps of Damghan city - fuzzy map of wind speed in Damghan city in terms of altitude in Damghan city. 


\section{DATA INTEGRATION}

By integrating the maps, the aim is to determine locations that are more suitable for building a wind farm. The output map created by merging the other maps is developed in a way that the amount of each spatial unit indicates how suitable a specified location is for the construction of a wind-driven power plant by considering all the effective factors. The model chosen, among many others, for integrating the developed data layers was the fuzzy model. This choice was made since the fuzzy model is stronger in integrating layers of information. The fuzzy logic method has been frequently used and applied for the combination of multiple-layered data in both executive and research projects.

Once the fuzzy factor map and restriction map were created, their integration was carried out through the application of fuzzy operators. The selection of suitable fuzzy operators for combining various layers considering the connections and interactions of the factors related to the layers is demanding. Choosing a fuzzy operator is largely dependent upon the types of spatial data that will be combined with each other. The integration of all the intended layers can often not be done using only one type of operator. Therefore, it is essential that in the majority of cases, data integration be carried out using several operators individually or in groups according to the nature and features of the layers. Compared with the other methods, the fuzzy method is more flexible in combining the factor maps. In the fuzzy method, one operator is usually not used for the integration of various layers of information; instead, by using a variety of operators, fuzzy inference networks will be formed. In this article, based on different logics, various inference networks have been designed and, by utilizing the operators shown in Figure 9, the fuzzy inference network was chosen to integrate the layers of information. In the designed inference networks, the integration process of all the maps does not occur in one whole step. In other words, the criteria are classified according to expert knowledge, their role and nature in determining a location, and their relationship with each other, then the respective data layers are combined in different stages. As was stated previously in the restriction map, selecting a suitable location from among the remaining areas for constructing wind-driven power plants is not possible. Thus, the fuzzy factor map was designed to resolve this issue and to assign each location a quantifiable value so that they could be compared in terms of their value. Finally, the fuzzy maps were combined by the fuzzy operators shown in Figure 10 and the fuzzy factor map was generated. The final output map is developed by the integration of the fuzzy factor map in the restriction map.

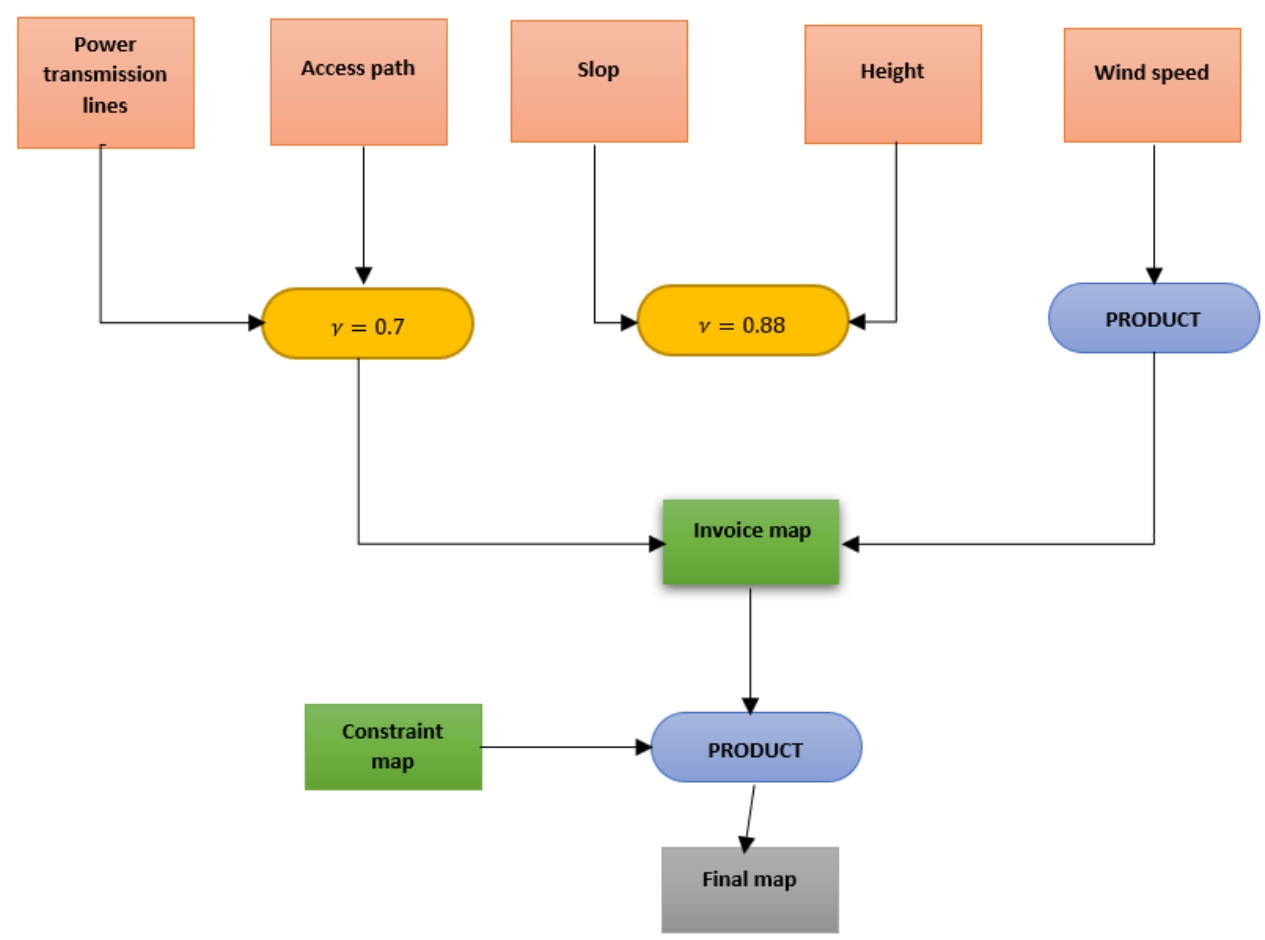

Figure 10. Inference network designed to integrate information layers. 
The weight of various fuzzy layers at the time of integration was determined through the AHP method according to Table 3 .

Table 3. Results of weight of different fuzzy layers by the AHP method

\begin{tabular}{l|c}
\hline Factor map layers & Factor weight \\
\hline Wind speed and wind class & 0.578633 \\
\hline Power transmission lines & 0.210974 \\
\hline Access routes & 0.132108 \\
\hline Land slope & 0.0497461 \\
\hline Above sea level & 0.0285292 \\
\hline
\end{tabular}

To give proper weight to the fuzzy layers, 20 questionnaires were prepared and administered to a group of experts, including university professors and scientific stakeholders. They were asked to fill out each questionnaire which were comprised of the criteria resulting from the research literature. They were also required to state their expert recommendations according to their knowledge base and scientific experiences. The expert comments were then compiled and the arithmetic and geometric means of the criteria were calculated. Table 3 was developed after determining the relative significance of the criteria and by considering the Inconsistency Coefficient. In this method, the coefficient was 0.13821 which is quite suitable (this amount needs to be less than 0.15) (Abdel-Basset et al., 2021).

Eventually, once the weight of each criterion was specified and by taking into account the fuzzy inference network Figure 10, the fuzzy factor map was developed. The final map, with an area of about 2,240 $\mathrm{Km}^{2}$, is created by the integration of the so-called fuzzy factor map with the restriction map shown in Figure 11. According to the obtained results from Figure 10, approximately 16\% of the lands in Damghan town are deemed suitable for the construction of wind-driven power plants (about $2,240 \mathrm{Km}^{2}$ out of the total $14,000 \mathrm{Km}^{2}$ of Damghan town).

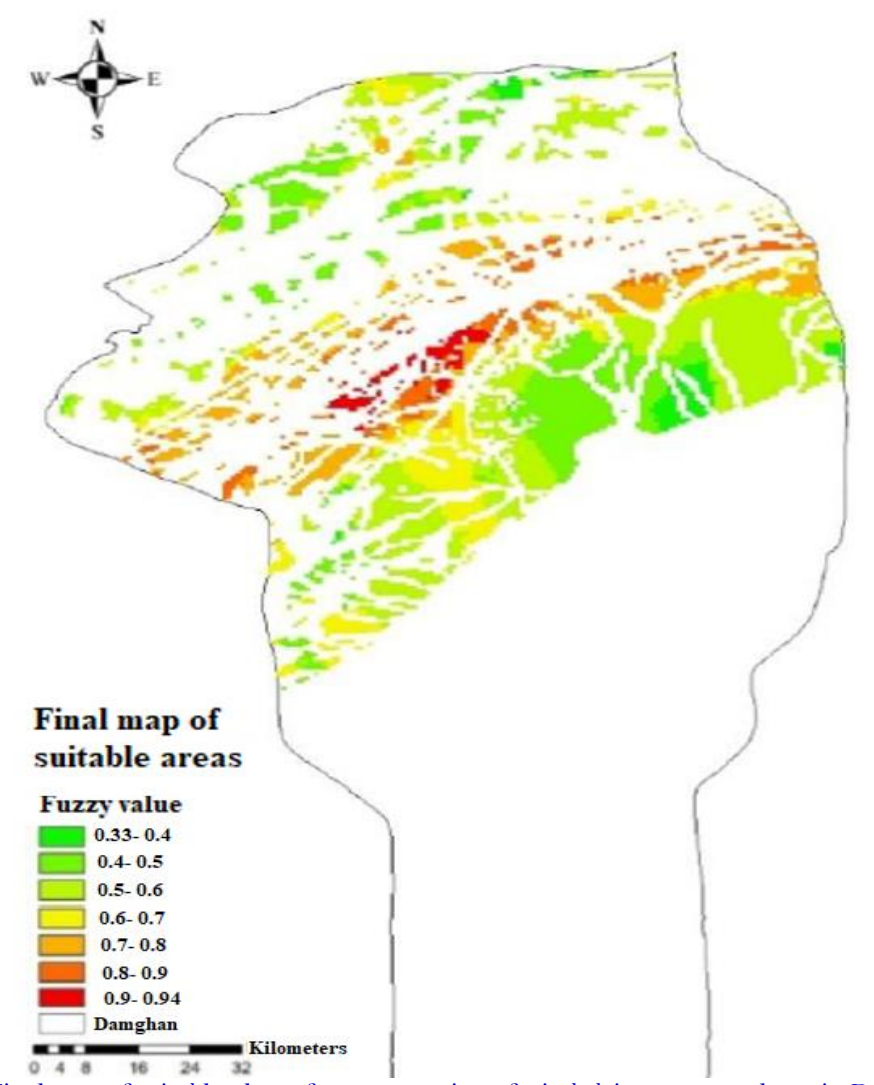

Figure 11. Final map of suitable places for construction of wind-driven power plants in Damghan city. 


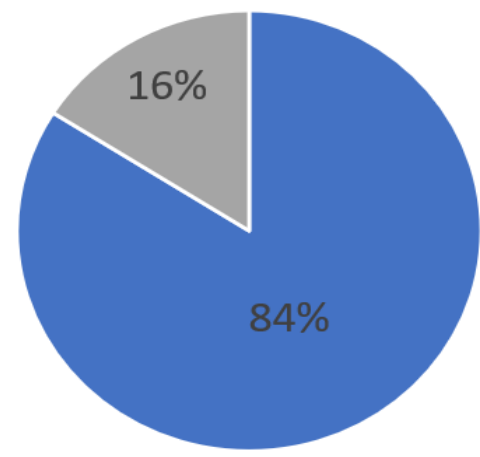

- Totall Area = Suitable Area

Figure 12. Classification of a suitable place for construction of a wind-driven power plant in Damghan city.

As shown in Figure 12, 60\% of the identified locations possess a fuzzy value of more than 0.5. Within the mentioned $60 \%$, ten percent of the sites are of a fuzzy value larger than 0.9 which makes them the most optimal in any respect for wind-driven power plant construction. Fifteen percent of the locations have a fuzzy value between 0.8 and 0.9 , and $25 \%$ of them are between 0.7 and 0.8 . Ten percent of the locations have a fuzzy value between 0.6 and 0.7 and between 0.5 and 0.6 , while $15 \%$ of the identified locations have a fuzzy value between 0.33 and 0.4 (the lowest fuzzy value is 0.33 ). The fuzzy value of $25 \%$ of the locations is between 0.4 and 0.5 , and, in total, $40 \%$ of the specified locations have a fuzzy value of less than 0.5.

Wind Pro software was used to validate the designed model, and the power density of the specified areas in Damghan city is also calculated using this software. The results of the calculations through Wind Pro are indicative of the high precision of the method used in this study. The validation results of the model using this software are shown in Table 4 and Figure 13.

Table 4. Comparison of different turbines for several wind farm samples in the final map.

\begin{tabular}{l|c|c|c|c|c|c|c|c}
\hline Turbine & Type & $\begin{array}{c}\text { Nominal } \\
\text { power } \\
(\mathbf{k W})\end{array}$ & $\begin{array}{c}\text { Blade } \\
\text { diameter } \\
\mathbf{( m )}\end{array}$ & $\begin{array}{c}\text { Hub } \\
\text { height } \\
\mathbf{( m )}\end{array}$ & $\begin{array}{c}\text { Annual } \\
\text { energy } \\
(\mathbf{M W h})\end{array}$ & $\begin{array}{c}\text { Annual } \\
\text { energy drop } \\
\text { by 10\% }\end{array}$ & $\begin{array}{c}\text { Medium } \\
\text { wind speed } \\
(\mathbf{m} / \mathbf{s})\end{array}$ & $\begin{array}{c}\text { Capacity } \\
\text { factor } \\
(\mathbf{\%})\end{array}$ \\
\hline VESTAS & V100 & 1800 & 100 & 80 & 5670.2 & 5103 & 6.18 & 35.9 \\
\hline HYUNDAI & HQ2000 & 2000 & 86.7 & 80 & 5087.4 & 4579 & 6.18 & 29 \\
\hline REpower & MM92 & 2000 & 92.5 & 80 & 5293.3 & 4764 & 6.18 & 30.2 \\
\hline SUZLON & S95 & 2100 & 92.5 & 79 & 5333.2 & 4800 & 6.17 & 29 \\
\hline
\end{tabular}

\section{Fuzzy Values}

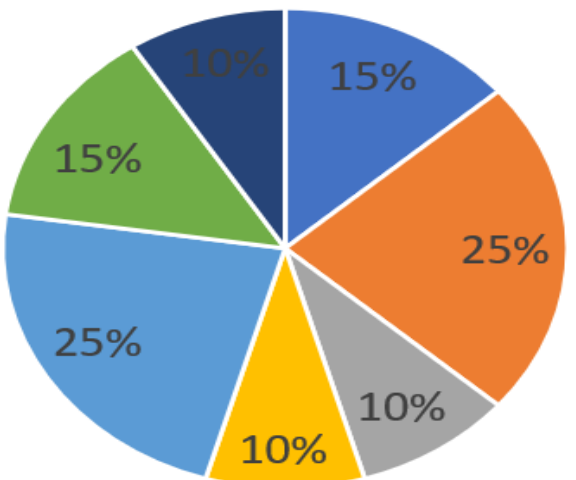

$$
\begin{aligned}
& \text { = 0.33-0.44 } \\
& =0.4-0.5 \\
& =0.5-0.6 \\
& =0.6-0.7 \\
& =0.7-0.8 \\
& =0.5-0.9 \\
& =0.9-10
\end{aligned}
$$

Figure 13. Model validation results (comparison of turbines) 
Finally, to calculate the probable amount of energy that can be produced by wind farms in Damghan town, statistics collected by weathers stations in Semnan province, which are of high importance for determining a suitable location, were analyzed using software like Wind Pro and WAsP. The average annual and monthly temperatures of the areas under investigations were also considered. Then, according to the arrangement of Lissaman wind turbines and by considering all the other criteria, and by observing appropriate distances from windfarms to not experience any power drop, the producible amount of power was calculated to be 1,000 Megawatts. Based on the studies carried out, the least amount of producible power by the use of wind energy in Damghan town is 30,000 Megawatt hours per month in the month of March Figure 14, thus more power could be produced using wind energy in the other 11 months.

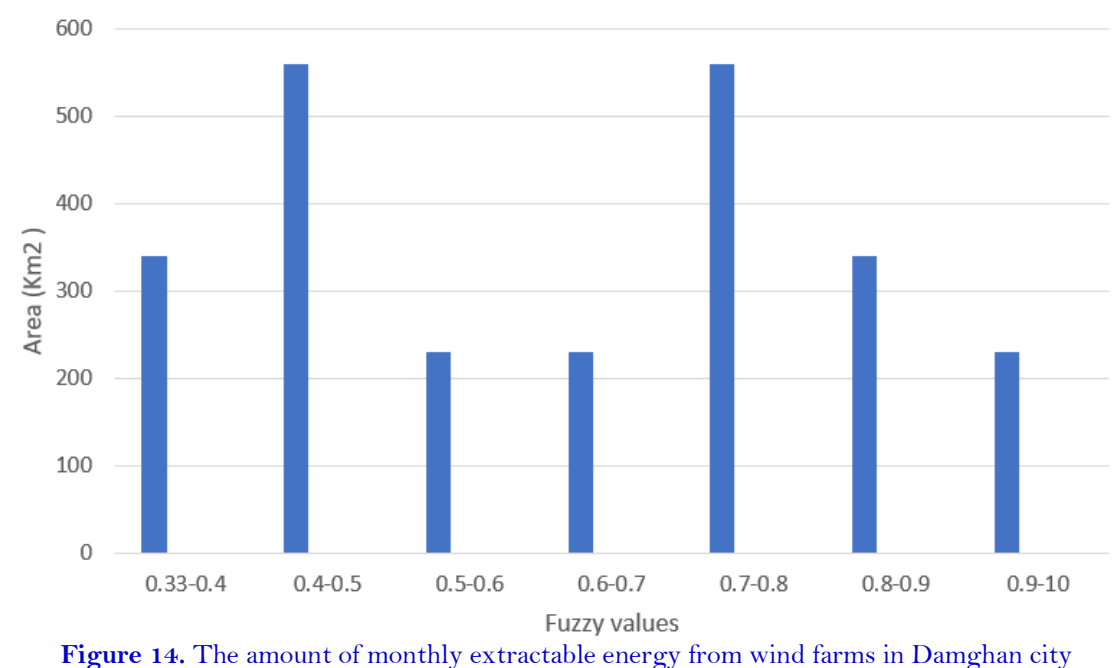

\section{CONCLUSION}

Damghan, a city in Semnan province in Iran, is a high-potential area regarding wind energy sources with the highest wind energy potential among all cities of Semnan province. In this research, in addition to the identification of significant parameters in selecting a location for a wind farm, the role and impact degree of each criterion is specified. Various maps of Damghan town, Semnan province, were developed according to roles and different impacts of a variety of factors using Geographic Information System (GIS) and Multi-Criteria Decision Making (MCDM) methods along with the AHP method for assigning values to the effective criteria. In the present study, $16 \%$ of Damghan town lands were identified as appropriate for the construction of wind farms, or approximately $2,240 \mathrm{Km}^{2}$ from the total 13,000 $\mathrm{Km}^{2}$. The possible power that could be produced from wind farms in Damghan town, by considering the previously mentioned criteria, and by observing an appropriate distance from other wind farms so as not to lose production power, is 1,000 Megawatts.

Funding: This study received no specific financial support.

Competing Interests: The authors declare that they have no competing interests.

Authors' Contributions: All authors contributed equally to the conception and design of the study.

\section{REFERENCES}

Abdel-Basset, M., Gamal, A., Chakrabortty, R. K., \& Ryan, M. (202 1). A new hybrid multi-criteria decision-making approach for location selection of sustainable offshore wind energy stations: A case study. Journal of Cleaner Production, 280, 124462.Available at: https://doi.org/10.1016/j.jclepro.2020.124462.

Akdağ, S. A., \& Güler, O. (2018). Alternative Moment Method for wind energy potential and turbine energy output estimation. Renewable Energy, 120, 69-77.Available at: https://doi.org/10.1016/j.renene.2017.12.072. 
Al-Yahyai, S., \& Charabi, Y. (2015). Assessment of large-scale wind energy potential in the emerging city of Duqm (Oman). Renewable and Sustainable Energy Reviews, 47, 438-447.Available at: https://doi.org/10.1016/j.rser.2015.03.024.

Allouhi, A., Zamzoum, O., Islam, M. R., Saidur, R., Kousksou, T., Jamil, A., \& Derouich, A. (2017). Evaluation of wind energy potential in Morocco's coastal regions. Renewable and Sustainable Energy Reviews, 72, 311-324.Available at: https://doi.org/10.1016/j.rser.2017.01.047.

Amarasinghe, A., \& Perera, E. (2021). Modeling predictive suitability to determine potential areas for establishing wind power plants in Sri Lanka. Modeling Earth Systems and Environment, 7(1), 443-454.Available at: https://doi.org/10.1007/s40808-020-00868-w.

Arreyndip, N. A., Joseph, E., \& David, A. (2016). Wind energy potential assessment of Cameroon's coastal regions for the installation of an onshore wind farm. Heliyon, 2(11), e00187.Available at: https://doi.org/10.1016/j.heliyon.2016.e00187.

Beiter, P., Musial, W., Smith, A., Kilcher, L., Damiani, R., Maness, M., \& Scott, G. (2016). A spatial-economic cost-reduction pathway analysis for US offshore wind energy development from 2015-2030 (No. NREL/TP-6A20-66579). United States: National Renewable Energy Lab.(NREL), Golden, CO.

Bina, S. M., Jalilinasrabady, S., Fujii, H., \& Farabi-Asl, H. (2018). A comprehensive approach for wind power plant potential assessment, application to northwestern Iran. Energy, 164, 344-358.Available at: https://doi.org/10.1016/j.energy.2018.08.211.

Dabbaghiyan, A., Fazelpour, F., Abnavi, M. D., \& Rosen, M. A. (2016). Evaluation of wind energy potential in province of Bushehr, Iran. Renewable and Sustainable Energy Reviews, 55, 455-466.Available at: https://doi.org/10.1016/j.rser.2015.10.148.

Dincer, F. (2011). The analysis on wind energy electricity generation status, potential and policies in the world. Renewable and Sustainable Energy Reviews, 15(9), 5135-5142.Available at: https://doi.org/10.1016/j.rser.2011.07.042.

El Khchine, Y., Sriti, M., \& Elyamani, N. E. E. K. (2019). Evaluation of wind energy potential and trends in Morocco. Heliyon, 5(6), e01830.Available at: https://doi.org/10.1016/j.heliyon.2019.e01830.

Elibol, B. (2015). Deep dive into power generatıon technology costs: Turkey. Hacettepe Journal, 7, 2930-2939.

Ellabban, O., Abu-Rub, H., \& Blaabjerg, F. (2014). Renewable energy resources: Current status, future prospects and their enabling technology. Renewable and Sustainable Energy Reviews, 39, 748-764.Available at: https://doi.org/10.1016/j.rser.2014.07.113.

Erfani, A., Ghasempour, R., \& Oraee, H. (2017). Issue in the technology selection for a Wind Farm in Iran. Journal of Energy Management and Technology, 1(1), 71-78.

Fazelpour, F., Soltani, N., Soltani, S., \& Rosen, M. A. (2015). Assessment of wind energy potential and economics in the northwestern Iranian cities of Tabriz and Ardabil. Renewable and Sustainable Energy Reviews, 45, 87-99.Available at: https://doi.org/10.1016/j.rser.2015.01.045.

Fazelpour, F., Markarian, E., \& Soltani, N. (2017). Wind energy potential and economic assessment of four locations in Sistan and Balouchestan province in Iran. Renewable Energy, 109, 646-667.Available at: https://doi.org/10.1016/j.renene.2017.03.072.

Haapala, K. R., \& Prempreeda, P. (2014). Comparative life cycle assessment of 2.0 MW wind turbines. International Journal of Sustainable Manufacturing, 3(2), 170-185.Available at: https://doi.org/10.1504/ijsm.2014.062496.

Hafeznia, H., Pourfayaz, F., \& Maleki, A. (2017). An assessment of Iran's natural gas potential for transition toward low-carbon economy. Renewable and Sustainable Energy Reviews, 79, 71-81.Available at: https://doi.org/10.1016/j.rser.2017.05.042.

Luankaeo, S., \& Tirawanichakul, Y. (2017). Assessment of wind energy potential in Prince of Songkla University (South Part of Thailand): Hatyai campus. Energy Procedia, 138, 704-709.Available at: https://doi.org/10.1016/j.egypro.2017.10.204.

Mahdy, M., \& Bahaj, A. S. (2018). Multi criteria decision analysis for offshore wind energy potential in Egypt. Renewable Energy, 118, 278-289.Available at: https://doi.org/10.1016/j.renene.2017.11.021.

Mirhosseini, M., Sharifi, F., \& Sedaghat, A. (2011). Assessing the wind energy potential locations in province of Semnan in Iran. Renewable and Sustainable Energy Reviews, 15(1), 449-459.Available at: https://doi.org/10.1016/j.rser.2010.09.029. 
Mohammadi, K., Mostafaeipour, A., \& Sabzpooshani, M. (2014). Assessment of solar and wind energy potentials for three free economic and industrial zones of Iran. Energy, 67, 117-128.Available at: https://doi.org/10.1016/j.energy.2014.02.024.

Moradi, S., Yousefi, H., Noorollahi, Y., \& Rosso, D. (2020). Multi-criteria decision support system for wind farm site selection and sensitivity analysis: Case study of Alborz Province, Iran. Energy Strategy Reviews, 29, 100478.Available at: https://doi.org/10.1016/j.esr.2020.100478.

Murthy, K. S. R., \& Rahi, O. P. (2016). Preliminary assessment of wind power potential over the coastal region of Bheemunipatnam in northern Andhra Pradesh, India. Renewable Energy, 99, 1137-1145.Available at: https://doi.org/10.1016/j.renene.2016.08.017.

Nazir, M. S., Alturise, F., Alshmrany, S., Nazir, H., Bilal, M., Abdalla, A. N., . . M Ali, Z. (2020). Wind generation forecasting methods and proliferation of artificial neural network: A review of five years research trend. Sustainability, 12(9), 127.Available at: https://doi.org/10.3390/su12093778.

Okeniyi, J. O., Moses, I. F., \& Okeniyi, E. T. (2015). Wind characteristics and energy potential assessment in Akure, South West Nigeria: Econometrics and policy implications. International Journal of Ambient Energy, 36(6), 282-300.Available at: https://doi.org/10.1080/01430750.2013.864586.

Premono, B., Tjahjana, D., \& Hadi, S. (2017). Wind energy potential assessment to estimate performance of selected wind turbine in northern coastal region of Semarang-Indonesia. Paper presented at the In AIP Conference Proceedings: AIP Publishing LLC.

Quan, P., \& Leephakpreeda, T. (2015). Assessment of wind energy potential for selecting wind turbines: An application to Thailand. Sustainable Energy Technologies and Assessments, 11, 17-26.Available at: https://doi.org/10.1016/j.seta.2015.05.002.

Rao, K. (2019). Global wind energy and power generation options: Socioeconomic factors, in Wind Energy for Power Generation (pp. 703-828). Cham: Springer.

Rehman, S., Natarajan, N., Vasudevan, M., \& Alhems, L. M. (2020). Assessment of wind energy potential across varying topographical features of Tamil Nadu, India. Energy Exploration E Exploitation, 38(1), 175-200.Available at: https://doi.org/10.1177/0144598719875276.

Rusu, E. (2020). An evaluation of the wind energy dynamics in the Baltic Sea, past and future projections. Renewable Energy, 160, 350-362.Available at: https://doi.org/10.1016/j.renene.2020.06.152.

Shu, Z., Li, Q., \& Chan, P. (2015). Statistical analysis of wind characteristics and wind energy potential in Hong Kong. Energy Conversion and Management, 101, 644-657.Available at: https://doi.org/10.1016/j.enconman.2015.05.070.

Sohrab, T., Rafiee, M., Karkoodi, S., \& Parvin, M. (2019). Estimation of the employment rate of wind power plants in Iran in the horizon of 2050. International Journal of Ambient Energy, 1-7.

Tavana, A., Javid, A. E., Houshfar, E., Andwari, A. M., Ashjaee, M., Shoaee, S., . . Marashi, F. (2019). Toward renewable and sustainable energies perspective in Iran. Renewable Energy, 139, 1194-1216.Available at: https://doi.org/10.1016/j.renene.2019.03.022.

Yang, W., Tavner, P. J., Crabtree, C. J., Feng, Y., \& Qiu, Y. (2014). Wind turbine condition monitoring: Technical and commercial challenges. Wind Energy, 17(5), 673-693.Available at: https://doi.org/10.1002/we.1508.

Zahedi, R., Ahmadi, A., \& Dashti, R. (2021). Energy, exergy, exergoeconomic and exergoenvironmental analysis and optimization of quadruple combined solar, biogas, SRC and ORC cycles with methane system. Renewable and Sustainable Energy Reviews, 150, 11 1420.Available at: https://doi.org/10.1016/j.rser.2021.111420.

Zahedi, R., Ahmadi, A., \& Sadeh, M. (2021). Investigation of the load management and environmental impact of the hybrid cogeneration of the wind power plant and fuel cell. Energy Reports, 7, 2930-2939.Available at: https://doi.org/10.1016/j.egyr.202 1.05.008.

Zahedi, R., \& Rad, A. B. (2022). Numerical and experimental simulation of gas-liquid two-phase flow in 90-degree elbow. Alexandria Engineering Journal, 61(3), 2536-2550.Available at: https://doi.org/10.1016/j.aej.2021.07.011.

Views and opinions expressed in this article are the views and opinions of the author(s), International Journal of Sustainable Energy and Environmental Research shall not be responsible or answerable for any loss, damage or liability etc. caused in relation to/arising out of the use of the content. 